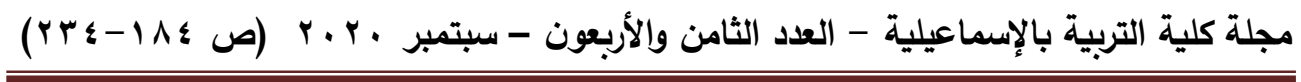

\title{
Developing the Speaking Skills of English as a Foreign Language (EFL) Preparatory Schoolers Using Self-Study Strategies
}

\begin{abstract}
By
Ahmed Mohamed Yaoud Ahmed*

\section{Introduction}

English language is considered the most widespread language all over the world. It is the international language used as the medium of information flow on science, technology and culture (Rokhmawati, 2011). It is also the language of diplomacy, business, trade and tourism (Badr, 2009). Nawaz (2005: 1) states that English gives us glimpse of the various development taking place in the world. It also provides up to date knowledge in all fields of human activity. Accordingly, it is the language of international communication. On the other hand, Haroun (2012 : 38) says, "In today's world, learning English is a vital skill that helps your children achieve their full potential in later life."

Speaking is one of the four main skills of English language. Richards (2008: 19) claims that the mastery of speaking skills in English is a priority for many second language or foreign language learners. Consequently, learners often evaluate their success in language learning as well as the effectiveness of their English course on the basis of how much they feel they have improved in their spoken language proficiency.

Sarac (2007 : 23) states that children learn to think, re-think and to critically examine other people's thinking as well as their own through the internalization of their talk. He also states that speaking enables pupils to take an active and reflective role in their own learning because it helps them order and re-order their thinking, solve problems and give reasons.

*Extracted from a Master's thesis supervised by:

Prof. Mohammed Ismail Abu Rahmah, Professor of TEFL, Faculty of Education, Ismailia, Suez Canal University.

Dr. Mohammed Abu El Magd, Associate Professor of TEFL, Faculty of Education, Ismailia, Suez Canal University.

* Senior Teacher of English at Al Oboor Preparatory School for Girls, Ismailia
\end{abstract}


According to Rokhmawati (2011: 2), speaking is a crucial part of the foreign language learning and teaching, because it can be used for the pupils to express their ideas orally in foreign language, and without speaking skill they will just keep silent. He also indicates that in order to speak well, pupils must practice their skill in everyday life. Therefore, the teacher should give them an opportunity to practice their speaking skill by giving some more examples or activities that put them into the real practice communication.

Gillis (2013) assures that the ability to speak skillfully provides the speaker with many important advantages: (1) ability to inform, persuade, and direct, (2) ability to stand out from the rest, (3) ability to benefit derivatively, and (4) career enhancement. He also emphasizes that speaking skills are important for career success, and can also enhance one's personal life.

Learning speaking is considered the most difficult for many EFL learners to master, because it needs the mastery of the linguistic and the culture competence. Shumin (1997) states that learning to speak a foreign language requires more than knowing its grammar and vocabulary. Learners should acquire the skill through interaction with each other. However, it is difficult for EFL learners to speak appropriate English in the classroom because of the limited language use in their real lives. Eggins and Slade (1997) claim that the problems related to speaking might either result from the teacher, the curriculum, the materials, or from the pupils themselves.

Shumin (2002) argues that speaking English is the most difficult for learners. In particular, EFL learners often stammer when speaking English. This results from learners' lack of exposure to authentic English language environments that allow them to use English for communication and expression. Furthermore, learners are not exposed to the cultures of the native English speakers.

Sarac (2007: 26) states that in order to develop the speaking skills needed for learners, they have to cope with a number of obstacles such as:

1. Mixed ability classes : It is difficult to organize a lesson that will fit all the different language levels of the pupils.

2. The arrangement of the classroom: In connection with the size of the classroom and the number of the pupils, pupils usually sit behind each other in classes in two rows.

3. The syllabus the coursebook: The speaking activities envisaged in the coursebook do not match the level and the needs of the pupils. 


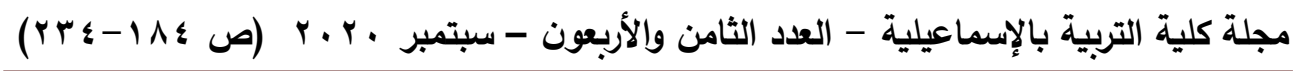

4. Lack of material: The only material is the ones provided by the publisher of the coursebook to support the lessons.

5. The effect of the mother tongue: Some pupils make up a sentence first in their mother tongue, then they translate it into English.

6. Lack of speaking assessment: Though tests and exams are applied in classes, speaking test is not envisaged within the assessment package.

To conclude, in spite of being the most difficult for learners to master, speaking is an important tool for communication, and without speech we cannot communicate with others easily. Hence, teachers should encourage and help learners use this skill in real life situations inside and outside the classroom to improve their speaking skills.

Context of the problem

As a teacher of English at a preparatory school, the researcher noticed that many preparatory stage pupils had some difficulties in speaking. In spite of being relatively good at reading and writing, it was difficult for them to produce oral language, and they usually avoid participating in class discussions. Therefore, a pilot study was conducted to explore the real situation among a class of $\mathbf{4 0}$ girls from Al Oboor Preparatory School for Girl in Ismailia during class. To obtain information from pupils about the problem, a questionnaire of four questions was supplied to the pupils inside the classroom. The pupils were asked about the problems they face when they speak English. They were allowed to answer in Arabic when they weren't able to express in English. The results revealed that there were many problems faced by the pupils and make them avoid participating in class discussions and speaking activities. The most repeated problems were shyness and fearing of mistakes, stammering, or being criticized by teachers and other pupils. Lack of motivation, lack of self-confidence and lack of information on the topics discussed were also mentioned by the pupils.

A group of six teachers of English and three supervisors of English were also interviewed. According to the interviewees and the results of the pilot study, the most common problems faced by the EFL learners in developing their speaking skills and made them avoid speaking in English as a foreign language were classified in three groups:

a) Problems related to the EFL learners:

1- Lack of motivation and self-confidence.

2- Lack of information on the topics discussed.

3- Shyness and fearing of mistakes, stammering, or being criticized by others.

4- Pupils don't practice speaking English outside the classroom. 
5- Neglecting speaking because no tests are given to them to assess their proficiency in it.

6- Pupils are used to thinking in Arabic when they speak English so Arabic interferes with their English speech.

7- Neglecting listening which is related to pronunciation, stress and intonation.

b) Problems related to teachers:

1- Some teachers overuse their mother tongue (Arabic) in EFL classes.

2- Some teachers pay much attention to how to do well in the written work only.

3- Some teachers feel useless if they allow their pupils to produce faulty English.

4- Some teachers avoid using new strategies and techniques in teaching.

c) Problems related to time, number of pupils and the coursebook:

1- The time provided for practicing speaking in speaking classes is too limited.

2- Classrooms are overcrowded with pupils and furniture.

3- Lack of speaking activities in the coursebook.

Hence, the present study attempted to help preparatory pupils in developing their speaking skills by using some self-study strategies which draw individual pupils' attention to the strengths and weaknesses of their performances individually.

Statement of the problem

In spite of the vital importance of the speaking skills, the findings of the pilot study have revealed deficiencies in the EFL preparatory pupils' speaking skills due to some problems faced by them, like shyness and fearing of mistakes, stammering, or being criticized by teachers and other pupils, lack of motivation, lack of self-confidence and lack of information. So those problems needed to be solved in order to develop the pupils' speaking skills.

Questions of the study

This study sought to find answers to the following questions:

1. What are the speaking skills required for EFL preparatory school pupils?

2. What are the features of some self-study strategies that may help them to develop their speaking skills?

3. What is the effect of those developed strategies on developing the speaking skills of the EFL preparatory pupils?

Hypotheses of the study 


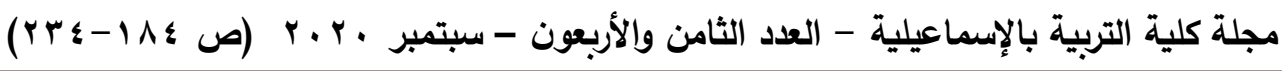

1. There is a statistically significant difference at 0.05 level between the mean scores of the experimental group in the pre administration of the speaking skills test and those of the post administration of the same test in favour of the post administration.

2. There is a statistically significant difference at 0.05 level between the mean scores of the experimental group and the control group in the post administration of the speaking skills test in favour of the experimental group.

\section{Aims of the study}

This study aimed at:

1- Developing speaking skills of the EFL first year preparatory pupils.

2- Preparing self-study tasks to develop speaking skills for the first year preparatory pupils.

3- Determining the effect of self-study strategies on developing speaking skills among first year preparatory pupils.

\section{Significance of the study}

This study can be beneficial to pupils not only in improving their interest in speaking English but also in improving their speaking skills. On the other hand, it helps EFL teachers to teach speaking through self-study strategies. It also help supervisors of English and curriculum developers.

\section{Delimitations of the Study}

The present study was limited to:

1. A sample of (72) $1^{\text {st }}$ year preparatory pupils from a governmental school in Ismailia governorate called Al Oboor Preparatory School for girls. This sample included two classes, one of them was assigned as the experimental group and the other one was assigned as the control group.

2. Some EFL speaking skills required for first year preparatory pupils, such as asking and answering questions related to specific topic, asking about and describe objects /materials / people and making comparisons Using appropriate vocabulary and using grammar rules correctly.

3. Some self-study strategies such as note-taking strategies and summarizing strategies. 


\section{Literature Review}

Part one: Speaking skills

1. Definitions of speaking skill

Because of the importance of speaking skill, it was defined in different ways". Nunan (2003:48) states that "Speaking is a productive aural/ oral skill and it consists of producing systematic verbal utterances to convey meaning". According to Hornby (2007:4), "Speaking is making use of words in an ordinary voice, uttering words, knowing and being able to use language; expressing oneself in words; making speech. While skill is the ability to do something well. Therefore, we can infer that speaking is the ability to make use of words or a language to express oneself in an ordinary voice".

Oxford Dictionary of Current English (2009:414) defines speaking as "the action of conveying information or expressing ones' thoughts and feelings in spoken languages." It is also defined by Irawati (2014: 26) as an activity to produce sayings in the form of words and sentences orally in order to communicate with others.

The researcher operationally defined speaking skill as the ability to produce speech in order to communicate with others, express feelings and ideas, and exchange information verbally and/or non-verbally in social contexts.

2. Nature of the speaking skill

Nature of the speaking skill is described by many researchers and linguists. It has some characteristics. These characteristics include the following:

a. Speaking is different from other skills

Speaking differs from writing and the other skills in many aspects. Badr (2009: 17) views that the speaking skill has a unique nature, which differs from that of the writing skill. These differences are due to (1) the vocabulary used in writing should be formal, while the vocabulary used in speaking skill should be informal, (2) complex sentences are used in writing, while speaking is characterized by simple structures and (3) there is a lack of sentence boundaries in speech but writing is characterized with sentence boundaries.

b. Speaking is the ability to produce language

Byrne (1990) as cited by Ibrahim (2007:49) states that speaking is the human ability of producing the language with its phonological, syntactic and semantic rules to express oneself meaningfully.

c. Speaking is social 


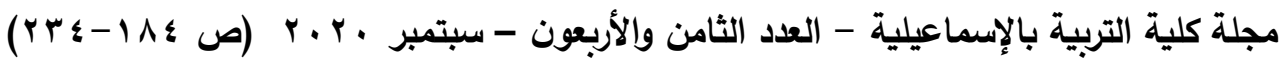

Thornbury and Slade (2006: 15- 17) claim that speaking is social, in the sense that it establishes relation and mutual agreement, maintains and modifies social identity, and involves interpersonal skills. This social element is expressed through wishes, feelings, attitudes, opinions and judgments, which can clash with the formal nature of the classroom when teaching speaking. They also state that speaking happens in a small group of people with a minimum of two.

d. Speaking is a complex skill

Hinkel (2005:485) states that speaking is the most complex and difficult skill to master. Syakur (2007:4) argues that speaking requires that not only knowing how to produce it well but also understanding when, what, and why to produce the language.

e. Speaking is a multi-sensory activity

According to Thornbury (2005:9), speaking is also a multi-sensory activity because it includes some nonverbal communication skills such as eye-contact, facial expressions, body language tempo, pauses and voice quality changes.

3. Speaking skill and language content

According to Khorashadyzadeh (2014: 12), speaking requires that learners not only know how to produce specific points of language such as grammar pronunciation, or vocabulary (linguistic competence), but also they understand when, why, and in what ways to produce language (sociolinguistic competence). In the same context, Brown (2001) states that learning to speak a foreign language requires more than knowing its grammatical and semantic rules, as pupils should know how native speakers use the language in daily interpersonal exchange. Syakur (2007:4) also states that there are at least five components of speaking skill concerned with comprehension, grammar, vocabulary, pronunciation, and fluency.

4. Features of the speaking lesson

Speaking lessons can follow the usual pattern of preparation, presentation, practice, evaluation, and extension. Nunan (1999: 241) emphasizes that in speaking classroom, learners should be given the maximum number of opportunities to practice the target language in meaningful contexts and situation. The opportunities are an integral part of a speaking class. The main task of an instructor is to help the pupil master the mechanical elements of language (pronunciation, grammar, and vocabulary), elements of language functions, and elements of sociocultural norms by providing authentic exercises that prepares them to interact in real communication. Instructors need to 
help pupils produce grammatical expressions, logical, and according to the situation of the speaking, and using an acceptable pronunciation. In Terry (2008)'s presentation about "How to teach speaking in an EFL class", it was proposed that a speaking lesson consists of three main stages, they are:

1. Pre-communicative stage: In this stage, teachers are supposed to introduce the communicative function, highlight the fixed expression, point out the target structure and provide pupils with the necessary vocabulary and the language of interaction.

2. Practice stage: In this stage, teachers prompt and correct pupils if necessary.

3. Communicative interaction or production stage: In this stage, teachers encourage language negotiation among pupils, take notes of any aspects that may hinder communication such as pronunciation, vocabulary, grammar, etc. After this stage, teachers give pupils feedback on pronunciation, grammar and vocabulary and ask pupils to repeat the task if necessary.

According to self-study strategies, speaking classroom learners are given the maximum number of opportunities to practice the target language in meaningful contexts and situation. They learn autonomously under the supervision of the teacher and the stages of lessons differ according to the self-study strategy used as we will see in the second part of this chapter.

5. Classroom Speaking tasks and activities

According to Brown (2001: 270), successful speaking activity must have some characteristics such as:

1. Learners talk a lot. As much as possible of the period of time allocated to the activity is in fact taken by learners talk.

2. Motivation is high. Learners are eager to speak because they are interested in the topic and have something new to say about it.

3. Language is of an acceptable level. Learners express themselves in utterances that are relevant, easy comprehensible and of acceptable level of language accuracy.

Yellen et al. (2004) state that the key to encouraging speaking skills in the classroom is creating the proper environment so the clever teacher is the one who creates the positive climate and the motivational activity, and the students do the rest.

For developing speaking skills, there are many class activities, such as discussions, role play, dialogue, dialogue improvisation, information 


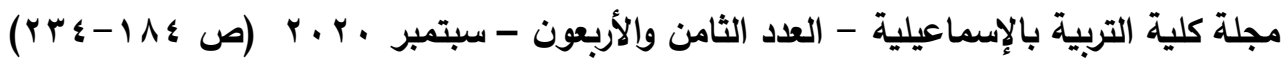

gaps, brainstorming, reporting, storytelling, interviews, picture describing, find the difference, prepared talks and pantomime.

Part two: Self-Study

1. Definitions of self-study

Khodabandehlou et al. (2012) state that since the late 1980s we have seen a proliferation of terms relating to this concept of terms relating to this concept of self-directed learning, autonomous learning, selfmonitoring, self-assessment, learner strategies, self-help learning strategies, learner training, self-study, self-access learning. The key concepts that have emerged, however, and around which others pivot, are those of learner autonomy as a goal for learners, and learner training, or the teacher's encouragement of their efforts towards that goal.

Many researchers, linguists and dictionaries define self-study as a style or a way of learning. Pinnegar (1998 : 33) defines self-study as "a methodology for studying professional practice settings". Hamilton et al (1998 : 236) also define self-study as "the study of one's self, one's actions, one's ideas, as well as the 'not self'... Self-study also involves a thoughtful look at texts read, experiences had, people known, and ideas considered".

In the Cambridge Dictionary (2016), "Self-study" is defined as "a way of learning about a subject that involves studying alone at home, rather than in a classroom with a teacher.

Self-study is also defined by the American Heritage Dictionary of the English Language (2013) as follows:

1. Study or examination of oneself.

2. A form of study in which one is to a large extent responsible for one's own instruction.

3. The study of something by oneself without direct supervision or attendance in a class.

4. The study of oneself; self-examination.

Cynthia et al. (2009: 9) state that self-study is defined according to the role, practice, and/or purpose.

a. Self-study defined by role:

Self-study involves a strong personal reference in that it involves study of the self and study by the self although there are variations of that theme. Hamilton et al. (1998: 236) define self-study as "the study of one's self, one's actions, one's ideas, as well as the 'not self'... Self-study also involves a thoughtful look at texts read, experiences had, people known, and ideas considered". 
b. Self-study defined by situated practice:

Beck et al. (2004) describe self-study as "a personal-constructivistcollaborative approach". Accordingly, self-study has three important overlapping components. Self-study is constructivist because it includes elements of ongoing inquiry, respects personal experience, and emphasizes the role of knowledge construction. Self-study is also collaborative because it acknowledges the important role of the social construction of knowledge.

c. Self-study defined by purpose:

LaBoskey (2004a) defines self-study work as moral and value-laden emphasizing the important moral and political purposes of self-study.

Based on the definition of Tang and Yang (2000:15) who define selfstudy as" a way to achieve some form of autonomous learning", the following definition was adopted in this study:

Self-study is a way of learning in which a learner is responsible for the learning situation under the supervision of the teacher. During this process the learner can interact with others.

According to this definition the role of the teacher is to:

1. give help when s/he is asked for.

2. promote critical thinking.

3. evaluate outcomes.

2. Nature of self-study

Although it seemed to be an approach to adult learning, self-study proved to be suitable to young learners. Knowles, (1970) proposed that five basic issues needed to be considered and addressed in establishing formal learning environment for adults:

1. Letting learners know why something is important to learn;

2. Showing learners how to direct themselves through information

3. Relating the topic to the learner's experiences;

4. People will not learn until they are ready and motivated to learn; and,

5. People must be helped to overcome inhibitions, behaviors, and beliefs about learning.

Finally, Knowles himself admitted that four of those five conditions for learning mentioned above, applied equally well to children, with the primary difference being that children have fewer experiences (Loughran et al., 2004 :44).

Cynthia et al. (2009: 5) assure that self-study focuses on improvement on both the personal and professional levels. Self-study builds on the personal processes of reflection and inquiry, and takes these processes 


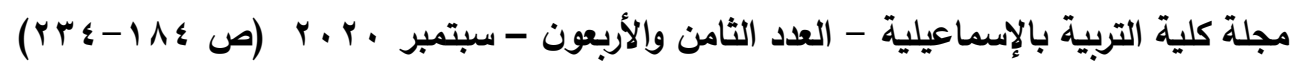

and makes them open to public critique. They say "Self-study is not done in isolation, but rather requires collaboration for building new understandings through dialogue and validation of findings. Self-study research requires openness and vulnerability since the focus is on the self. Finally, self-study is designed to lead to the reframing and reconceptualizing of the role of the teacher."

Cynthia et al. (2009) also identify three additional characteristics that distinguish nature of self-study from other forms of research. These characteristics are: (1) paradoxical, (2) postmodern, and (3) multiple and multifaceted.

They state that self-study seems paradoxical according to LaBoskey, ( 2004a) as she states that the term self-study suggests that the study is about the individual, and yet self-study researchers assert that it must involve collaboration and "critical friends" or trusted colleagues. She also states that self-study is by its very nature, democratic and encouraging of critical reflection.

To conclude, it can be said that self-study is:

1- suitable to both adults and young learners,

2- democratic and encouraging of critical reflection,

3- requires openness and vulnerability and designed to lead to the reframing,

4- reconceptualizing of the role of the teacher,

5- paradoxical as it seems to be about the individual and at the same time it must involve collaboration, and;

6- multiple, multifaceted and includes many methods.

3.Importance of self-study and learner autonomy

Self-study is important by its nature because self-study activities always attract learners as they become more independent and responsible for their work. They also take the learners from the teacher pressure environment to another learning environment in which they are able to control the learning process and make their learning more effective. Clarke and Erickson (2003) claim that without self-study, teaching becomes repetitive not reflective-merely the duplication of models and strategies learned elsewhere and brought to bear unproblematic ally in one's own classroom.

According to TARGETSTUDY. EDUCATION. KNOWLEDGE. CENTER. (n.d.), self-study

has many advantages as follows:

1. It helps pupils broaden their thinking level.

2. Freedom of learning without any restriction. 
3. Self-learning would enable the learner to limit the number of interests undertaken.

4. Self-learning is more fun than regular teaching.

5. Pupils tend to build a sense of responsibility and they start accepting responsibility.

6. Pupils may learn at their own desired time according to their schedule.

7. Self-learning pupils tend to retain more naturally when they do the work themselves, as compared to the regular teaching where teacher's spoon feed the information to them.

8. It gives self confidence and a good feeling of doing a job well.

9. Self-learning gives an opportunity to the enthusiastic people to go as deeply into a subject and interact with the subject matter as deeply as they would like to go.

10. No fear of criticism.

Because of its importance as the philosophy of self-study, self-directed learning, autonomous learning, self-monitoring, self-assessment, learner strategies, self-help learning strategies, learner training and self-access learning the researcher of the present study talks about the importance of learner autonomy as follows.

Bocanegra et al. (1999) indicates that autonomy enables children to; (1) encounter, manipulate, and observe new knowledge to construct meaning for themselves; (2) become producers of language rather than simply learners of a linguistic system and; (3) develop an explicit understanding of the purpose of their learning as well as learning activities and outcomes.

Little (2002a) argues that learners who enjoy a high degree of social autonomy in their learning environment especially the classroom should find it easier than otherwise to master the full range of discourse roles that generate effective and spontaneous communication in real life situations. Palfreyman (2003) also claims that learner autonomy improves the quality of language learning, promotes democratic societies, prepares individuals for life-long learning, that it is a human right, and that it allows learners to make best use of learning opportunities in and out of the classroom.

Jiao 2005; Little (2006) assure that learner autonomy increases motivation. This occurs because the learner is the decision-maker in the classroom in contrast to traditional classrooms where teacher is the only wielder of power. Therefore, the learners feel more independent rather than teacher-dependent. Yan Liu (2012) also agrees that 


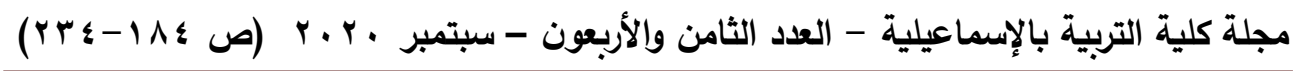

autonomous learners develop the reflective and attitudinal resources to overcome temporary motivational setbacks; and become more motivated to think and work independently. Moreover, they will know what they need and will engender their independent thoughts, as well.

Developing learners' autonomy means developing learners' "ability" and "willingness" together with knowledge, skills, motivation and confidence (Benson, 2001; Youssef, 2006). Gökgöz (2008) also claims that fostering autonomy will not only be a remedy for learners' improving their language skills but also enable them to create and make use of all the opportunities to communicate their message even in EFL setting. Murray (2009) adds that learner autonomy aims to create a non-threatening environment in language learning that helps learners feel ease and supports them to enhance learning and to use their probabilities to the fullest extent.

Hozayen (2011) argues that fostering autonomy in language learning among pupils in the Arab Academy has become inevitable in order to resolve some of the persisting problems. In short, teachers must always encourage their pupils to transfer their autonomous language learning strategies to their learning in general and thus empowering them to become life-long knowledgeable, creative and inquisitive learners.

Based upon what has been mentioned, self-study and autonomous learning seem to be important especially for the $21^{\text {st }}$ century learners who seek for liberty, rebel against the traditional methods and need to have this ability to reach the standard of the changing world. In order that pupils should be encouraged to take more responsibility in their own learning for the sake of making teaching and learning more effective through using self-study strategies.

4. Study skills related to self-study and learner autonomy

Study skills are defined by many linguistics as strategies and methods to efficiently manage learning. Study skills consist of time management strategies, note taking and active listening abilities, and summarization and analysis skills.

In order to be successful in learning a foreign language, pupils need to develop some other study skills which are necessary for autonomous language learning. These skills are:

1. " understanding the purpose of their learning;

2. accepting responsibility for their learning first;

3. being actively involved in the search for appropriate learning materials; and 
4. regularly monitoring and evaluating their own progress" (Holec, 1981).

Biggs (2003) posits three levels of skills that are required for pupils to become independent learners. These levels of skills are:

1. Generic study skills

He defines generic study skills as "ways of managing time and space" (2003, p. 93-94). These skills may include time-management, keeping track of deadlines, prioritizing, taking notes, developing effective presentation skills, referencing correctly, and the skills for effective elearning.

2. Study skills related to specific content

Study skills that relate to particular content include the following:

a. reading for meaning, not detail, underlining key words in passages,

b. taking notes properly by capturing the main idea of several sentences

in one's own words,

c. using concept maps to derive a major structure,

d. composing essays according to preplanned structures, and

e. using review and revisions.

3. Metacognitive learning skills

Metacognitive skills include the following:

a. self-management skills that are focused on what the learner does in new contexts,

b. developing strategies to solve problems,

c. learning from experience,

d. learning independently of a lecturer,

e. self-evaluating and self-monitoring, and

f. developing the capability to learn from both peer feedback and selfassessment.

To conclude, self-study pupils need some special study skills. These skills differs according to the levels of pupils. The researcher of the present study prepared a list of self-study skills that are appropriate to preparatory pupils and related to speaking skill.

5. The role of the teacher in self-study and learner autonomy

Self-study of pupils should require special attention on the part of teachers. Thanasoulas (2000) states that autonomous learning is by no means "teacherless learning." He also indicates that "learner autonomy does not mean that the teacher becomes redundant, abdicating his/her control over what is transpiring in the language learning process".

Little (1995) claims that "Learner autonomy depends on teacher autonomy", so teachers cannot be expected to foster the growth of 


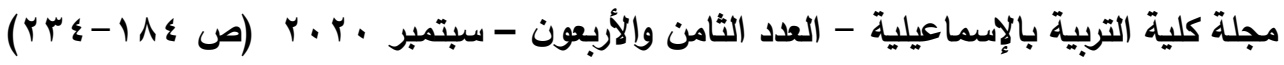

autonomy in their learners if they do not themselves know what it is to be an autonomous learner. They also must be able to exploit their professional skills autonomously.

Little (2004) asserts that "Teachers are indispensable", and explains as follows:

1. Learner-centered pedagogies have generated numerous attempts to redefine the teacher's role: facilitator, counsellor, manager of learning resources.

2. Changing the terms we use to describe what teachers do in no way diminishes their responsibility for making things happen: the teacher's key role is to create and maintain a learning community; if teachers stop teaching, most learners will stop learning.

Murray (2009) claims that a teacher always works as a facilitator providing the learners vast materials to choose, needed tools, equipments, proper guidance and support which will create their interest as well as will bring out the learners' maximum proficiency.

According to Shvets (2012), the task of the teacher is to help pupils organise their self-study thoughtfully and carefully, find effective ways of working, so that they can continue working efficiently and usefully even when they are away from their teacher and the classroom. The teacher should provide an environment and create the atmosphere in the language classroom in which pupils can learn. The other tasks of the teacher are to:

1. raise pupils' awareness about how they are learning;

2. make the learning process transparent for pupils;

3. help pupils develop their cognitive abilities;

4. get them actively involved in the learning process.

Liu (2012) explains the relationship between teachers and pupils in the learning process indicating that the teacher's role becomes slightly changed; teaching and learning should not always be controlled by the teacher, but should guide and help pupils to learn by themselves. Jamila (2013) also indicates that an autonomous class shifts a teacher-centered classroom into a learner-centered one. Accordingly, teachers always remain friendly and work as facilitator to the learners which create a positive environment of learning and learners feel safe and can easily rely on them without being much tensed.

To conclude, it is necessary for teachers working on an autonomous education to give up their traditional role as they control all aspects of the learning process, and change their role from provider of information to counselor and manager of learning resources, helping 
their learners be more autonomous and able to solve problems for themselves.

6. Some examples of self-study strategies

A. Note-Taking Strategies

Note-taking is, simply, a way of concisely recording important information so that you can recall it later. It is also a powerful aid to communication, a way of summarising and retaining the key points from what you've heard and understood (Note-Taking, (n.d.)).

Piolat et al.(2005) argue that non-linear styles of note-taking are more effective than linear styles

because non-linear styles facilitate the process of making connections between idea units, which enhances learning through deeper processing and strengthens long-term retention of content. Additionally, systematic behavioral procedures that train pupils to be effective note- takers may not only enhance the accuracy of content within their notes but also improve learning outcomes.

Friedman (2014) states that in contrast, non-linear styles that use graphical representations (e.g., allow pupils to organize the content of their notes in a systematic, yet unconventional fashion that may be difficult for others to understand easily. Importantly, whatever style of note-taking the learner chooses to adapt (linear, non-linear, or a combination of the two). The differences between note styles has a minimal impact on content comprehension.

There many different techniques of note-taking will be discussed as follows:

1. The mapping method

Mapping is a method that uses comprehension/concentration skills and evolves in a note taking form which relates each fact or idea to every other fact or idea. Mapping is a graphic representation of the content of a lecture. It is a method that maximizes active participation, affords immediate knowledge as to its understanding, and emphasizes critical thinking (Note Taking Systems, (n.d.)).

Mapping allows us to see the total picture. Mind map can show relationships and how the parts relate to the whole.

Steps to follow:

1. You need several sheets of blank paper, standard size.

2. Print the main subject in the middle of the page and draw a geometric shape around it.

3. All ideas plotted on a mind map should be expressed in just one or two key words. 


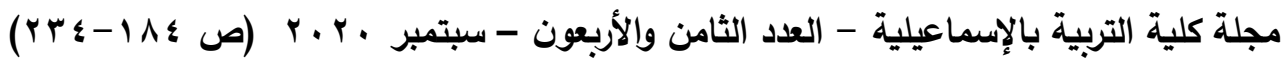

4. Key words should be concrete, meaningful, and summon up the same image or idea.

5. Think of subtopics that will represent all the data. The supporting points come after subtopics.

Advantages:

1. The main idea is more clearly defined.

2. The relative importance of each idea is clearly indicated. More important ideas will be nearer the center and less important ideas will be near the edge.

3. The links between the key concepts will be immediately recognizable because of proximity and connection.

4. Recall and review will be more effective and rapid.

5. Structure allows for the easy addition of new information without scratching out. Each map will look different, aiding recall.

6. It is easy to edit your notes by adding numbers, marks, and color coding.

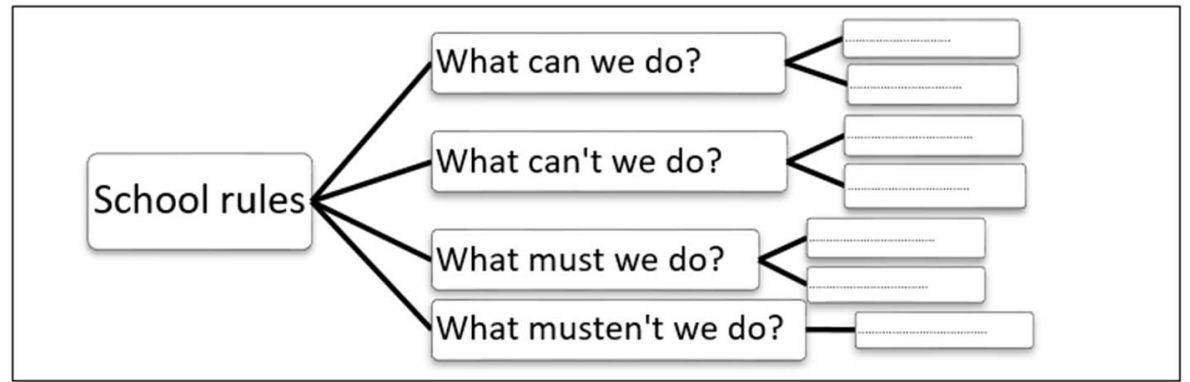

Figure (1): An Example of mind mapping

\section{Cornell Method}

The Cornell Method is one of the most popular note-taking strategies amongst pupils today. Cornell Notes are formatted such that pages of notes are split lengthwise: the right side of the page is used for formal notes while the left side of the page is reserved for keywords and questions relevant to the notes on the right. At the bottom or footer of each page, the note-taker writes a brief summary of that page of notes (Friedman, 2014).

\begin{tabular}{|l||l||}
\hline \hline Key words & Class notes \\
\hline \hline & \\
& \\
\hline \hline Summary & \\
\hline
\end{tabular}


Figure (2): An Example of Cornell Notes framework Advantages

1. Results in more organized notes.

2. Allows pupils to quickly identify key words and concepts.

3. Can easily be used as a study guide for exams.

4. Arrangement of information is aesthetically pleasing and easy to scan.

5. Help pupils make connections between ideas, synthesize information.

6. One advantage of Cornell Notes is that allows greater flexibility because they could be incorporated with the linear and non-linear styles (Note Taking Strategies, (n.d.)).

3. Skeleton Notes

With skeleton notes, the teacher provides a framework for pupils to write in key information. This strategy differs from teacher prepared notes in that pupils have the responsibility of writing in key information. Skeleton notes are helpful in teaching pupils how to organize ideas in a logical order. The teacher should be sure that the words or phrases pupils are asked to fill in represent some of the critical information, rather than the fillers.

4. Two-Column Notes

Two-column notes link a study strategy with the way in which information is organized and recorded. On the left-hand side of the page, pupils write down major topics or headings. Picking out the broad concepts for the left-hand side of the page gives pupils practice in identifying and classifying main ideas. Supporting details are written down on the right-hand side of the page. This step allows pupils an opportunity to think about the details of a concept or process. When studying the notes, pupils look at one side at a time, and rely on memory to fill in the other side.

Steps:

1. Divide the paper into a right and left side with a line down the middle.

2. Record broad concepts or "headings" on the left.

3. Record supporting details on the right.

4. Fold the paper in half to study and read either the concepts or the details, and use memory to recall the other.

5. Combination Notes

The note page has two columns. The left column is for notes and the right column is for illustrations. Combination notes are useful for pupils who learn well through visuals. By adding a sketch to an 


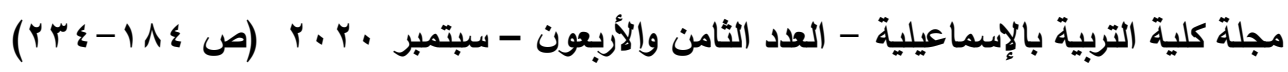
informal outline, pupils draw a picture to help them understand and recall information.

\begin{tabular}{|l|l||}
\hline Topic & Graphic \\
\hline \hline Notes & \\
\hline & \\
\hline Sutline & \\
\hline
\end{tabular}

Figure (3): An Example of Combination notes framework

6. The SQ3R Study Method

Another popular technique which matches the five R's, is the SQ3R method. This method has five steps and must be done in the proper sequence for the best results. This approach is primarily for reading textbooks but can be used for classroom discussions.

1. Survey: This simply means to scan the written material. This quick review should reveal the general content and structure of the concepts. Scan the headings, subheadings, topic sentences of paragraphs, graphics, and pictures. This will provide a clear overview of the information to be covered.

2. Question: Develop questions concerning what the materials are about. As the learner scans the material, generate questions to be answered later by careful reading.

3. Read: Read all of the material carefully and look for the answers to the questions that were developed. Learners should take notes as they read the material, which expands of the concepts and answers to the questions.

4. Recite: Learners should rephrase notes into their own words.

5. Review: Again as in the five R's, learners should periodically review their notes to keep the information fresh in their mind. Again, there are many study methods and this method is only one of many. We offer it to add to your toolbox. 


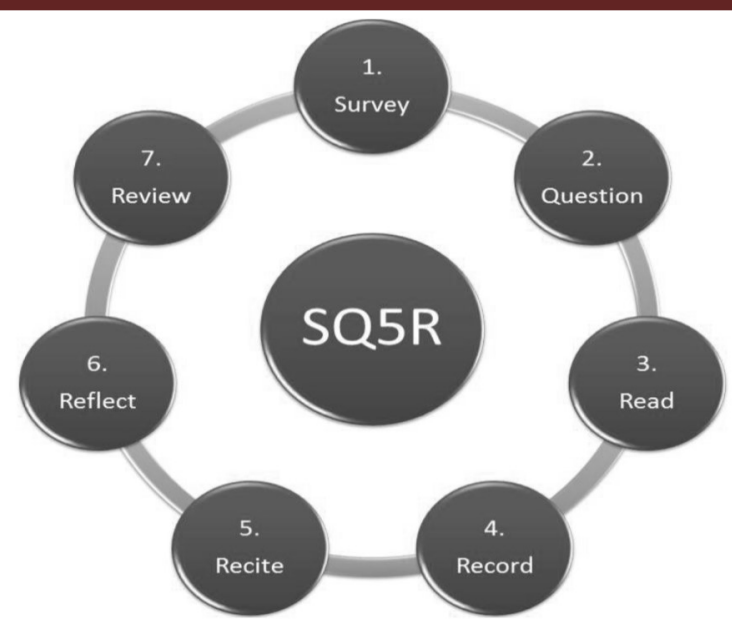

Figure (4): The SQ3R Study Method

Source: Wong (2006).

B. Strategies related to summarizing

Summarizing and note taking are part of the same category of instructional strategies because both require pupils to distill information (Marzano et al., 2000). The following are some of the summarizing strategies:

1. Think-Pair-Share

Think-Pair-Share is a cooperative discussion strategy where pupils talk about the content and discuss ideas before sharing with a whole group. It introduces the elements of "think time" and peer interaction, which are two important features of cooperative learning. Think-Pair-Share's purpose is to help pupils process information, develop communication skills, and refine their thinking. With this strategy the teacher:

a. Poses an open-ended question or problem.

b. Gives pupils a minute or two to think about their answer, pairs pupils to discuss the answer and share ideas.

c. Gives opportunities for pupils to share their response with a small group or the whole class.

2. Think-Write-Share

Pupils are given a topic/question. Pupils think about a question, write a response, then share with their partners.

3. 5 W's Summary

Pupils list information that answers Who, What, When, Where, Why related to the learning from the lesson. 


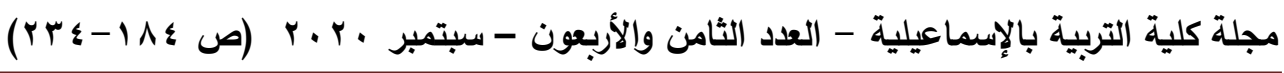

Who: Identify and make a list of the characters in a picture, a video or a reading passage.

What: Identify the things, events or actions.

Where: Identify all the places.

When: Identify all the time factors.

Why: Identify the causes for events or actions. Then describe the relationship among the characters, events, places or times.

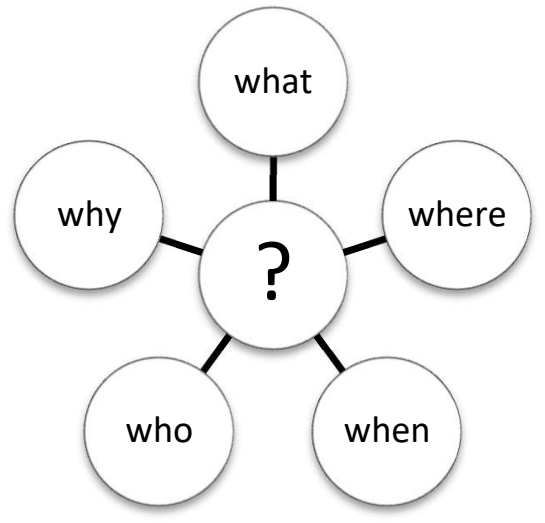

Figure (5): 5 W's Summary

4. The KWL strategy

This strategy (accessing what I know, determining what I want to find out, recalling what did I learned) combines several elements of approaches. The first two steps of KWL, pupils and the teacher engage in oral discussion. They reflect on their knowledge about a topic, brainstorm a group list of ideas about the topic, and identify categories of information. Next the teacher helps highlight gaps and inconsistencies in pupils' knowledge and pupils create individual lists of things that they want to learn about the topic or questions that they want to answer about the topic. In the last step of the strategy, pupils read new materials and share what they have learned.

C. Graphic Organizers

Graphic organizers are visual displays of key content information designed to benefit learners who have difficulty organizing information (Fisher \& Schumaker, 1995). Some graphic organizers focus on one particular content area (Merkley \& Jeffries, 2000). They have some important advantages as follows:

1. They are meant to help pupils clearly visualize how ideas are organized within a text or surrounding a concept. 
2. Graphic organizers can help pupils organize information; process information; see the relationships between ideas; and more easily understand, remember, and apply information (Baxendell, 2003).

3 . There are many different types of graphic organizers. The following are some of them and their uses (Marzano et al., 2000):

1. Graphic Organizers for Classification

Graphic organizers provide pupils with a visual guide to the classifying process. Pupils can be encouraged to use these graphic organizers as they complete their classification tasks. Two of the more popular graphic organizers used for classification are:

a. Classification table (Column format)

Pupils can use this organizer to sort or classify information or objects into different categories. They work in groups, pairs or individually to make a list of objects in the classroom. Then classify them into categories of their choosing. Use categories that show their understanding of the topic. When they are finished, pairs of pupils discuss what they learned.

\begin{tabular}{|c|c|c|c|}
\hline wood & plastic & glass & metal \\
\hline ….................. & …................... & …............... & .............. \\
\hline …................... & 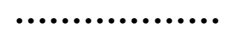 & …................... & ........................ \\
\hline 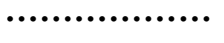 & 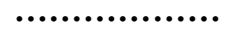 & 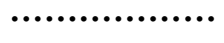 & …............ \\
\hline ….................... & 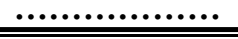 & (..................... & (..................... \\
\hline
\end{tabular}

Figure (6): Classification table ( Column format for Classification )

d. Web format

Pupils can use a web to categorize or classify items.

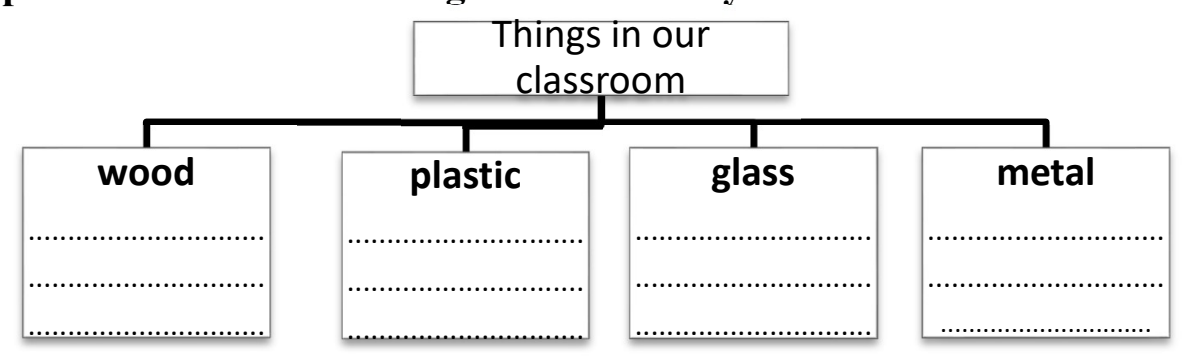

Figure (7): Web format

2. Graphic Organizers for Comparison

Comparing is the process of identifying similarities and differences between or among things or ideas. Comparing activities have broad applications. They can be used with any subject area, at any grade level. The key to an effective comparison is the identification of important characteristics that enhance pupils' understanding of the similarities and differences between the items being compared. Graphic Organizers 


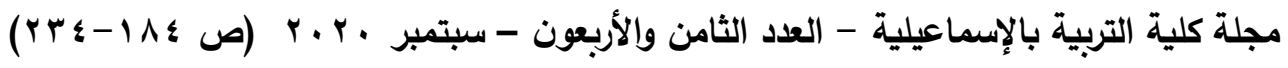

for Comparison allow pupils compare and contrast information according to various criteria. The more common graphic organizers used for comparison are:

a. The Venn diagram

The Venn diagram gives pupils a way to visually see the similarities and differences between two items. The similarities are listed in the intersection between the two circles. The differences are listed in the parts of each circle that do not intersect (Marzano et al., 2000).

This method uses diagrams to identify linkages and overlaps in ideas or perceptions. These commonalties are the used to a shared understanding of a issue, problem, or situation. The Venn Diagram is made up of two or more overlapping circles. They are used to describe and compare elements and characteristics of a situation (Friedman, 2014).
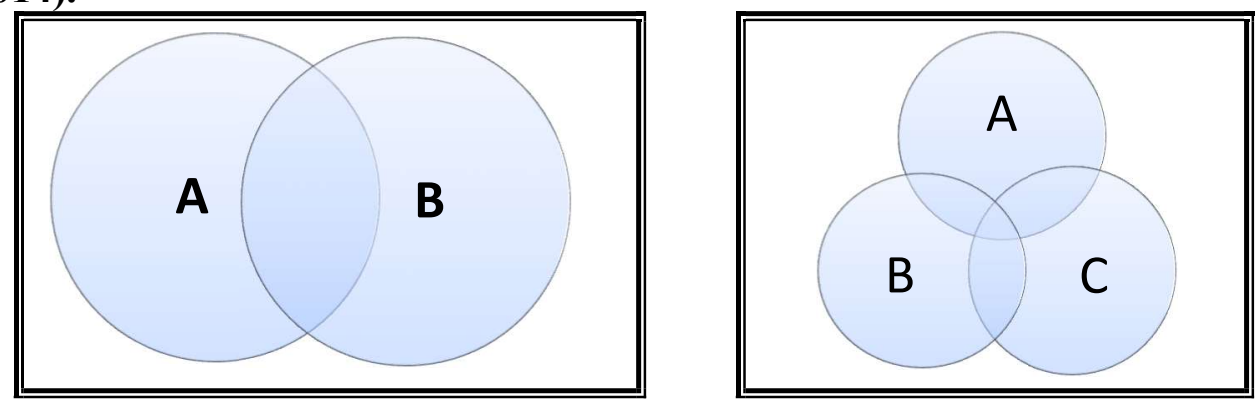

Figure (8): Examples of Venn Diagram

b. The comparison matrix

The comparison matrix graphically depicts a more detailed approach to the comparison process than does the Venn diagram.

\begin{tabular}{||l|l|l|l||}
\hline \hline \multirow{2}{*}{ Characteristics } & \multicolumn{2}{|l||}{ Items to be compared } & Similarities(SIM)/ \\
& $n \ldots \ldots \ldots \ldots \ldots$. & $\ldots \ldots \ldots \ldots$ & Differences (DIFF) \\
\hline & & & SIM.... \\
\cline { 4 - 4 } & & & DIFF..... \\
\hline & & SIM.... \\
& & DIFF..... \\
\hline
\end{tabular}

Figure (9): An Example of The comparison matrix

c. Graphic Organizers for Describing

The more common graphic organizers used for describing are Word webs. They help pupils to better understand a key vocabulary term by connecting it to related terms. (Available at http://iris.peabody.vanderbilt.edu, Retrieved on May 25th 2016).

3. Graphic Organizers for Sequencing 
a. Timeline: This simple and familiar type of graphic organizer arranges events in chronological order to help pupils better grasp the relationship between historical occurrences or developments.

b. Cycle: This variety of graphic organizer can help pupils to more fully comprehend series of events or phenomena that take on recurrent patterns.

D. Reinforcing Effort

Unlike the other categories of instructional strategies reviewed in this manual, this category does not deal directly with enhancing or engaging pupils' cognitive skills. However, reinforcing effort and providing recognition are strategies that deal with pupils' attitudes and beliefs and, thus, are likely to affect pupils' level of engagement in cognitive processes (Marzano et al., 2000).

1. Use the Pause, Prompt, and Praise Strategy

Teachers and/or tutors can adapt and use the "pause, prompt, and praise" technique to give pupils immediate, specific, and contingent praise (Merrett \& Thorpe, 1996). This strategy works particularly well with pupils who are struggling with a challenging task.

Teacher can use prompt cards to help pupils remember what to say, or to do. Prompt cards can be used in the classroom, to prompt/encourage pupils. These cards often contain pictures of things, or numbers. They also provide a list of language appropriate prompts that are relevant to each topic and are aimed at improving efficient communication as they remind us for the sake of confidence, not to think too well of others.

2. Use Concrete Symbols of Recognition

Symbolic tokens, such as stickers, certificates, or treats, can be effective tools for recognizing the successful completion of specific learning goals (Marzano et al., 2000).

E. Homework and practice

Homework and practice are instructional strategies that are well known to teachers. Both provide pupils with opportunities to deepen their understanding and proficiency in any content area. Homework also gives pupils an opportunity to learn new information and skills and to practice skills they have recently learned. But practice is an effective instructional strategy even when it is not part of a homework assignment.

F. Cooperative learning

According to Roger Johnson and David Johnson, there are five defining elements of cooperative learning:

1. positive interdependence (a sense of sink or swim together), 


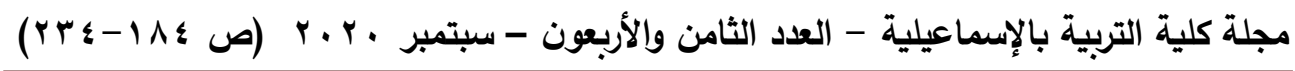

2. face-to-face promotive interaction (helping one another learn, applauding effort and success),

3. individual and group accountability (each of us has to contribute to the group achieving its goals),

4. interpersonal and small group skills (communication, trust, leadership, decision making, and conflict resolution), and;

5. group processing (reflecting on how well the team is functioning and how it can function even better) (Johnson, Johnson, \& Holubec, 1993).

G. Voice Recording

Pupils use technologies to record their voice. They listen to themselves. Then, they compare their own recordings and the ones recorded by the teacher in order to identify their weaknesses and strengths and to find their own mistakes. This helps pupils correct their mistakes and improve their pronunciation. It also promotes learners' awareness through self-reflection and self-assessment of their own recordings.

To conclude, self-study strategies seemed to be important in learning and teaching English. These strategies also seemed to be more interesting than the traditional methods in teaching and learning speaking skill as they are the key to creating the proper environment that encourages pupils' participation in speaking activities in and outside classrooms, so I adopted some of them to develop some speaking skills.

Design and the participants of the study

To achieve the aim of this study, two classes from Al Oboor Preparatory School for Girls in Ismailia were selected purposefully. One class was the experimental group and the other was the control one. Each group consisted of (36) female pupils. The treatment was administrated during the second term of the school year (2017-2018). Both groups were pre-tested to be sure that they are equivalent. The researcher used independent sample t-test for achieving the equivalence between the two groups in pre- measures. Then the experimental group was taught by using self-study strategies. The control group was taught through the ordinary method.

Instruments of the study

The researcher made the following instruments:

1. A speaking skills checklist

2. A self-study skills checklist

3. A speaking skills test 
4. A speaking assessment rubric

5. Learning material based on self-study strategies for developing speaking skills

A speaking skills checklist

This instrument was made to answer the first question of the study " What are the speaking skills required for EFL preparatory pupils?"

To make this instrument, the researcher reviewed literature and previous studies related to the variables of the study and; in light of the directives of the Ministry of Education in Egypt for general preparatory school pupils, and the pupils' text books (2015/2016), a list of the speaking skills seemed to be necessary for the EFL first year preparatory was provided. It was validated by a jury of judges, professors of TEFL at some faculties of Education in Egypt and some supervisors of EFL at General Preparatory Stage.

The final version of speaking skills includes 18 sub-skills. These subskills were divided into three groups. The first group "Interaction speaking skills" contains three sub-skills. These sub-skills involved in using talk for interaction as they describe interaction which serves a primarily social functions and refer to what we normally mean "Conversation". The second group "Transaction speaking skills" contains ten sub-skills. These sub-skills involved in using talk as transaction because they refer to language functions or situations where the focus on what is said or done. The third group "performance speaking skills" contains five sub-skills that refer to the way to transmit information (See appendix 1).

\section{A self-study skills checklist}

In order choose the self-study strategies that are suitable to the preparatory stage, literature was reviewed and a self-study skills checklist was prepared, then it was submitted to some Jury members to be validated (See appendix 2 ).

A Speaking skills test

The speaking skills test is one of the study instruments. It was prepared by the researcher to measure the participants' performance level in the speaking skills. To build this instrument, literature and previous studies were reviewed then, an initial version of speaking skills test was prepared in light of the directives of the Ministry of Education, for general preparatory stage pupils and submitted to some Jury members to ensure that it was valid to measure EFL speaking skills. Test-retest method was applied on a group of 20 first year preparatory pupils from 


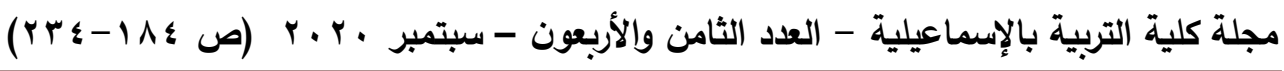

Al Oboor Preparatory School for Girls in Ismailia. Those pupils were not included in the study participants to compute the reliability of the test. The findings of using Pearson correlation between the twice applications was " 0.899 " which revealed that the test was reliable.

a. Aims of the Speaking Skills Test

The test aimed at measuring the effect of using some self-study strategies on developing speaking skills for the $1^{\text {st }}$ year preparatory pupils. It also aimed at helping the researcher test the hypotheses of the study.

b. Description of the Speaking Skills Test

The speaking skills test was designed to test pupils' speaking proficiency regarding six aspects: fluency, pronunciation, grammar, vocabulary, comprehension and nonverbal communications. It was administered as pre-test and post test. The instruments of these tests were a sheet for instructions, some cards, some pictures and a Speaking Assessment Rubric to help the assessors assess the pupils' performance. The test was designed with different types of questions. It was divided into five major questions. Participants were tested individually except in question five as they were tested in pairs (See appendix 3).

c. Test time identification

Time that each pupil took during the application of the first part of the test on the pilot study was between $(5-12)$ minutes for each pupil and the total time was about (160) minutes. In order to estimate the time needed for this part of the speaking skills test, the researcher calculated the arithmetic mean using the following formula: $\mu=\frac{\sum x}{n}=\frac{160}{20}=8$ minutes Where: $\mu$ : Arithmetic mean, $\sum x$ : Sum of the total time and $n$ : Number of the participants

The same formula was also used to estimate the time needed for the second part of the speaking skills test. $\mu=\frac{\sum x}{n}=\frac{60}{20}=3$ minutes

Thus, it was decided that the time for test completion is 11 minutes, eight minutes for each individual to complete the first part of the test and three minutes for each pair to complete the second part.

4. A speaking assessment rubric

To assess the participants' performance on the pre-post speaking skills test, the researcher designed a Speaking Assessment Rubric. It was also submitted with the test to jury of judges to give their opinions on it. The speaking assessment rubric helped in assessing participants' performance on six criteria: fluency, pronunciation, grammar, vocabulary, comprehension and nonverbal communication. The 
speaking skills test was marked out of 120 marks. Each question was marked out of 24 divided on six criteria, four marks for each criteria (See appendix 4).

In order to avoid subjectivity of evaluation, not only the researcher assessed the participant's performance but it was also assessed by another English teacher in the same session of the test. Then, the mean score of the two evaluations was recorded.

Learning materials based on self-study strategies for developing speaking skills

\section{a. Purpose}

Developing the speaking skills of EFL preparatory pupils using selfstudy strategies.

b. Intended Learning Outcomes

By the end of these sessions, preparatory first year pupil will be able to:

1. ask and answer about how to stay safe in the kitchen,

2. express necessity and obligation to talk about rules (e.g. school rules),

3. ask for and offer help,

4. ask and answer about using modern technology

5. ask and answer about similarities and differences,

6. make comparisons,

7. talk about various topics (e.g. taking care of possessions),

8. ask and answer questions related to a specific topic,

9. ask about and describe objects / materials / pictures / people / scenes

10. Ask and answer about countries and nationalities

c. Learning Inputs:

Table (1) Teaching Sessions

\begin{tabular}{|c|c|c|c|}
\hline & ILO & Language Input & Self-study strategies used \\
\hline 1 . & $\begin{array}{l}\text { Ask and answer } \\
\text { about staying safe in the } \\
\text { kitchen }\end{array}$ & $\begin{array}{l}\text { Unit 15, Lesson } \\
1, \text { Activity } 1 \text {, } \\
\text { p.29 }\end{array}$ & $\begin{array}{l}\text { 1. } \quad \text { Taking-notes (mind map / } \\
\text { Cornell notes) } \\
2 . \quad 5 \text { 's }\end{array}$ \\
\hline 2. & $\begin{array}{l}\text { Discuss what you } \\
\text { can / can't / must / mustn't } \\
\text { do at school }\end{array}$ & $\begin{array}{l}\text { Unit 15, Lesson } \\
2, \quad \text { Activity } 3 \text {, } \\
\text { p.30 }\end{array}$ & $\begin{array}{l}\text { 1. K-W-L (what I know, what } \\
\text { I want to find out, what I learned ) } \\
\text { 2. Taking-notes (Mind map) }\end{array}$ \\
\hline 3. & Ask for and offer & $\begin{array}{l}\text { Unit 15, Lesson } \\
3 \text {, Activity } 4, \\
\text { p.31 }\end{array}$ & Prompt cards \\
\hline 4. & Ask and answer & Unit 16, Lesson & Taking-notes $\quad($ Cornell \\
\hline
\end{tabular}




\begin{tabular}{|c|c|c|c|}
\hline & $\begin{array}{l}\text { about using modern } \\
\text { technology }\end{array}$ & $\begin{array}{l}\text { 1, Activity } 1, \\
\text { p.36 }\end{array}$ & $\begin{array}{l}\text { notes / mind map) } \\
2 . \quad \text { Voice Recording }\end{array}$ \\
\hline & $\begin{array}{l}\text { - Ask and answer about } \\
\text { similarities and differences } \\
\text { - Make } \\
\text { comparisons }\end{array}$ & $\begin{array}{l}\text { Unit 16, Lesson } \\
3, \quad \text { Activity } 4, \\
\text { p.38 }\end{array}$ & $\begin{array}{l}\text { Venn diagram } \\
\text { Voice Recording }\end{array}$ \\
\hline & ILO & Language Input & Self-study strategies used \\
\hline 6 & $\begin{array}{l}-\quad \text { Ask and answer } \\
\text { about problems in a } \\
\text { picture }\end{array}$ & $\begin{array}{l}\text { Unit 16, Lesson } \\
4, \quad \text { Activity } \quad 1, \\
\text { p.39 }\end{array}$ & $\begin{array}{lll}1 . & \text { Taking-notes } \quad \text { (Skeleton } \\
\text { notes) } & \\
2 . \quad \text { Voice Recording } & \end{array}$ \\
\hline 7 & $\begin{array}{l}\text { - Discuss taking } \\
\text { care of your possessions }\end{array}$ & $\begin{array}{l}\text { Unit } 16 \text {, Lesson } \\
\text { 4, Activity } 3, \\
\text { p.39 }\end{array}$ & $\begin{array}{l}\text { 1. Think-pair-share } \\
\text { 2. KWL (what I know, what I } \\
\text { want to find out, what I learned) }\end{array}$ \\
\hline 8 & $\begin{array}{l}\text { - Talk about what } \\
\text { things are made of }\end{array}$ & $\begin{array}{l}\text { Unit } 17, \text { Lesson } \\
1, \quad \text { Activity } 1, \\
\text { p.41 }\end{array}$ & $\begin{array}{l}\text { 1. Graphic Organizers for } \\
\text { Classification ( Column format or } \\
\text { Web format to classify items) }\end{array}$ \\
\hline 9. & $\begin{array}{l}\text { - Ask and answer } \\
\text { about classroom objects }\end{array}$ & $\begin{array}{l}\text { Unit } 17 \text {, Lesson } \\
2, \quad \text { Activity } 3, \\
\text { p.42 }\end{array}$ & $\begin{array}{l}\text { Taking-notes ( Mind map) } \\
\text { Think-write-share }\end{array}$ \\
\hline 10. & $\begin{array}{l}\text { - Talk about } \\
\text { countries and nationalities }\end{array}$ & $\begin{array}{l}\text { Unit 17, Lesson } \\
3, \quad \text { Activity } 1, \\
\text { p.43 }\end{array}$ & $\begin{array}{l}\text { 1. Graphic Organizers for } \\
\text { Classification (Column format or } \\
\text { Web format to classify items ) } \\
\text { 2. Think-pair-share }\end{array}$ \\
\hline 11. & $\begin{array}{l}\text { Ask about and } \\
\text { describe objects }\end{array}$ & $\begin{array}{l}\text { Unit } 17 \text {, Lesson } \\
5, \quad \text { Activity } 1, \\
\text { p.43 }\end{array}$ & $\begin{array}{l}\text { 1. Taking-notes (Combination } \\
\text { notes) } \\
\text { 2. } \quad \text { Think-write-share }\end{array}$ \\
\hline
\end{tabular}

\section{Methodology}

This section answered the second question of the study " What are the features of some self-study strategies that may help them develop their speaking skills?"

In teaching the instructional material, the researcher adopted some self-study strategies that seem to be relevant to the first year preparatory pupils to help them develop some of their speaking skills. They also help pupils to be active during the learning process. These self-study strategies help pupils to be partly responsible for learning. During this process, the teacher tries to create the appropriate 
environment to encourage speaking skills in the classroom. They also encourage social interaction among pupils.

Self-study strategies adopted are :

1. Note-taking strategies:

a. The mapping method

This strategy was adopted because of the following advantages:

1. The main idea is more clearly defined.

2. The relative importance of each idea is clearly indicated. More important ideas will be nearer the center and less important ideas will be near the edge.

3. The links between the key concepts will be immediately recognizable because of proximity and connection.

4. Structure allows for the easy addition of new information without scratching out or squeezing in.

5. Recall and review will be more effective and rapid.

6. It is easy to edit your notes by adding numbers, marks, and color coding.

Miraza (2016) conducted a study to find out whether mind mapping improves students' speaking ability or not and to find out how does mind mapping strategy improves students' speaking ability. The findings of the study revealed that mind mapping strategy improved students' speaking ability and helped them generate idea while speaking. Finally, the writer concluded that mind mapping strategy is one of strategies which can be used in order to improve the students' speaking ability.

b. Cornell Method

The reasons behind adopting this strategy are:

1. It results in more organized notes.

2. It can easily be used as a study guide for exams.

3. Arrangement of information is aesthetically pleasing and easy to scan.

4. It helps students make connections between ideas, synthesize information.

5. It allows students to quickly identify key words and concepts.

6. One advantage of Cornell Notes is that allows greater flexibility. because they could be incorporated with the linear and non-linear styles.

c. Skeleton Notes

Skeleton notes are helpful in teaching students how to organize ideas in a logical order. 


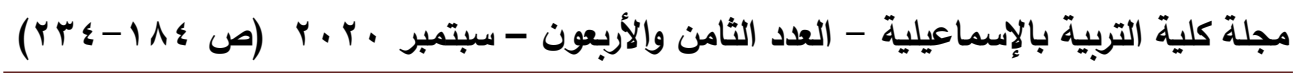

d. Combination notes

Combination notes are useful for students who learn well through visuals. By adding a sketch to an informal outline, students draw a picture to help them understand and recall information.

2. Summarizing strategies:

a. 5w's strategy

This strategy help pupils list information that answers Who, What, When, Where, Why related to the learning from the lesson.

- Who: Identify and make a list of the characters in a picture, a video or a reading passage.

- What: Identify the things, events or actions.

- Where: Identify all the places.

- When: Identify all the time factors.

- Why: Identify the causes for events or actions. Then describe the relationship among the characters, events, places or times.

b. KWL strategy

Mantra (2016) conducted a study to attempt at improving Speaking skill through Know, Want, and Learned (KWL) strategy to the students of English Study Program, Faculty of Teacher Training and Education, Mahasaraswati Denpasar. The findings of the study revealed that KWL could be used to improve the students' speaking skill. In addition, the result of the percentage analysis of questionnaire scores was clearly shown significant improvement in the students' learning motivation in learning speaking during the implementation of KWL strategy. Therefore, these findings clearly suggested that improving speaking skill through KWL strategy was highly effective.

c. Think-pair-share

Think-Pair-Share's purpose is to help students process information, develop communication skills, and refine their thinking. In his research, Usman (2015) proved that the think-pair-share strategy was effective to be implemented at STAIN Ternate in order to improve the students' speaking ability.

d. Think-write-share: It is similar to Think-Pair-Share.

3. Graphic organizers

Tayib, (2015) conducted a study to investigate the effectiveness of graphic organizers onstudents' writing ability as well as their attitudes towards this essential language skill. The results of this study proved that the graphic organizers model had significantly improved the students' writing ability and had positively impacted their attitudes towards this skill. These results suggested that graphic organizers could 
be an effective support in teaching writing of learners of English as a foreign language. Therefore, the present study tried to use graphic organizers to improve the first year preparatory schoolers' speaking skills.

a. Graphic organizers for classification (Column format or Web format to classify items)

b. Graphic organizers for comparison (Venn diagram)

4. Prompt cards

Prompt cards are used to help pupils remember what to say, or to do. They also provide a list of language appropriate prompts that are relevant to each topic and are aimed at improving efficient communication as they remind us for the sake of confidence, not to think too well of others.

5. Voice recording

Voice recording helps pupils identify their weaknesses and strengths and to find their own mistakes. It also helps them correct their mistakes and improve their pronunciation. It promotes learners' awareness through self-reflection and self-assessment.

Lessons layout (An exemplary lesson)

ILO: By the end of this session the pupils will be able to:

- $\quad$ ask and answer about staying safe in the kitchen.

Language Input: Unit 15, Lesson 1, Activity 1, p.29

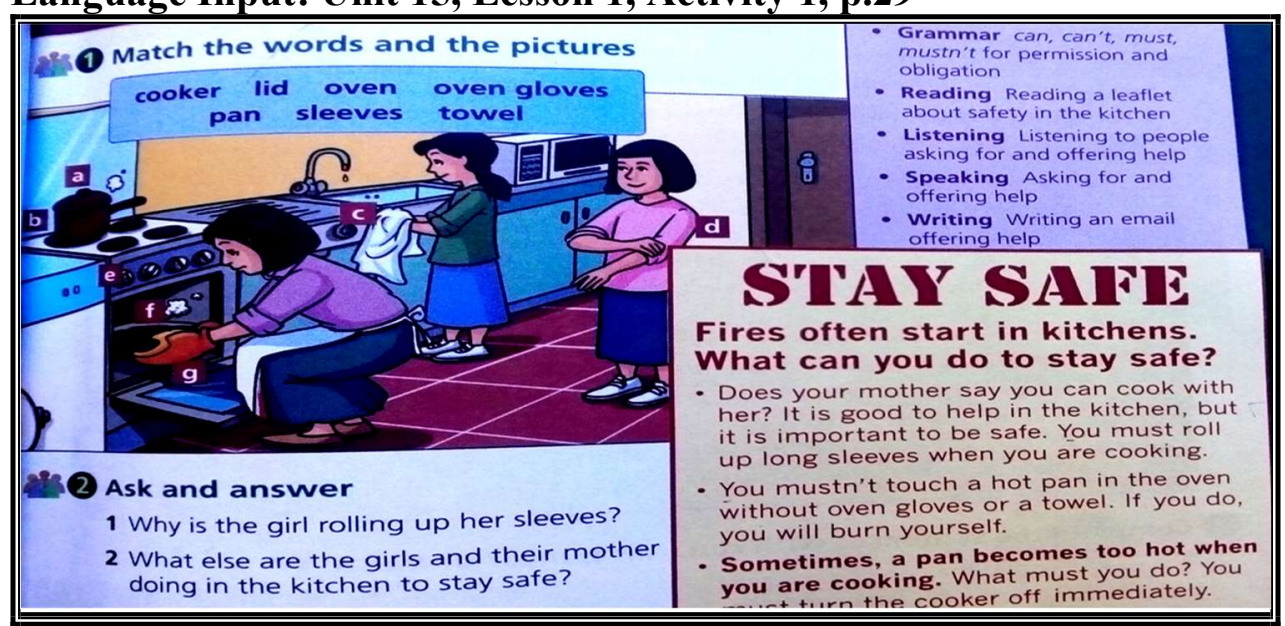

Source: New Hello English (2015:29)

Self-study strategies:

1. Taking-note (mind map / Cornell notes) 2. 5w's strategy

Tasks and activities:

1. The teacher tells the pupils the aim of the task. 


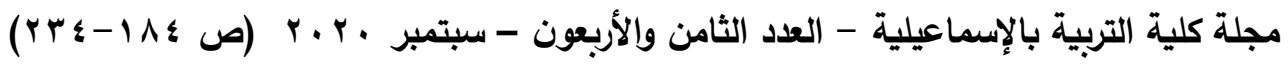

2. Pupils look at the picture in Ex. 1.

3. The teacher asks pupils to say anything about it.

4. The teacher reads the words in the box and checks if the pupils know them.

5. On the board, the teacher draws a map of 5w's questions.

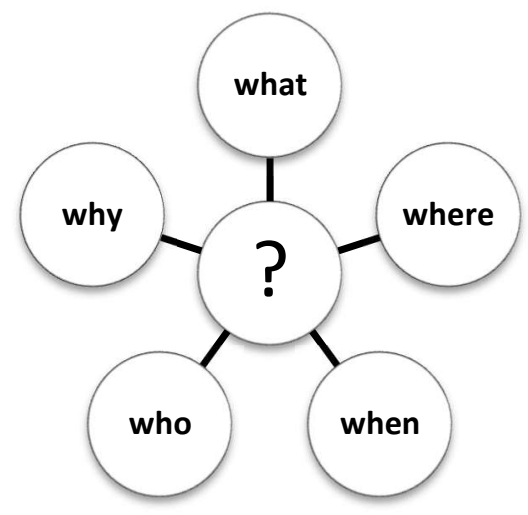

6. Pupils look at the picture again and work in groups to:

a- make 5w's questions about the picture.

b- list information that answers the questions.( In a table prepared by the teacher, pupils write their notes only in words not complete sentences ).

\begin{tabular}{|l|l||}
\hline Key questions & Notes ( answers ) \\
\hline \hline Who & \\
\hline Where & \\
\hline What & \\
\hline When & \\
\hline Why & \\
\hline
\end{tabular}

7. After finishing their notes, the teacher invites pairs of pupils, a pupil asks a question and the other pupil answers.( e.g. S1: Where are they? S2: They are in the kitchen.)

8. The teacher invites individuals to say three more sentences about the picture.

9. The teacher asks " Is it important to stay safe at home?" and lets the pupils answer.( The expected answer is "Yes".)

10. The teacher writes a main question on the board "How can we stay safe in the kitchen?" 
11. Pupils are divided into small groups. Each group has a blank mind map prepared by the teacher.

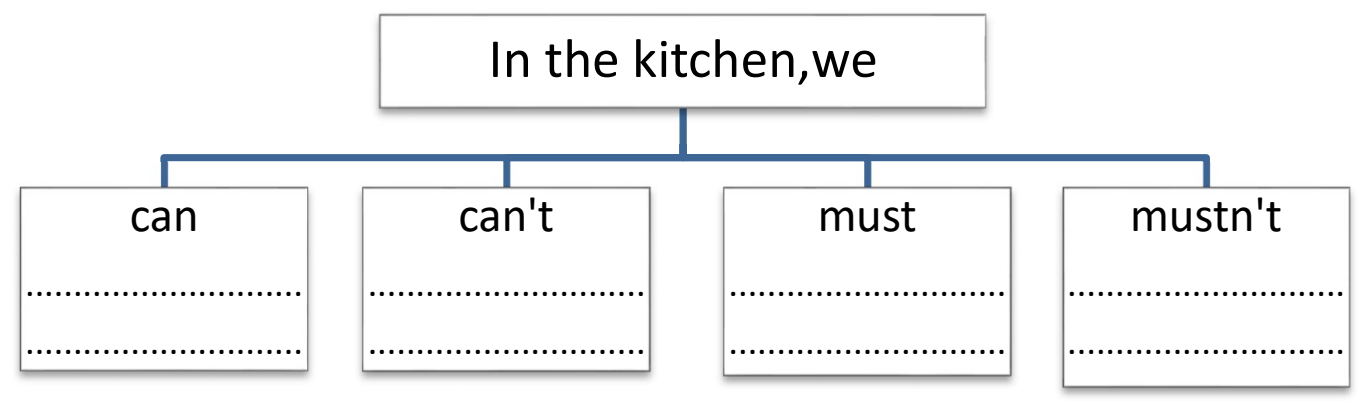

12. The teacher explains that we use "can" for permission and the negative is " can't" and we use "must" for obligation and the negative is " mustn't".

13. Pupil are asked to think about the question and fill in the blank mind map.

\section{Assessment}

1- Randomly the teacher invites two pupils from different groups, one of them ask and the other one answers.

S1: What can/can't/must/mustn't we do to be safe in the kitchen?

S2: We can/can't/must/mustn't

2- $\quad$ The teacher invites individuals to say three more sentences about staying safe in the kitchen.

\section{Implementation of the treatment}

a. Pre-test

Before starting the treatment, the speaking skills test was administered to both the experimental group and the control one in order to ensure that they are equivalent in mastering speaking skill. The researcher used independent sample t-test for achieving the equivalence between the two groups in the pre- measures. The means, standard deviation and " $t$ " value were also computed, then there are the following statistical results:

Table (2): Results of Pre-Test between the Experimental and the Control Groups

\begin{tabular}{||l|l|l|l|l|l|l|l||}
\hline \hline & groups & $\mathrm{N}$ & Mean & $\begin{array}{l}\text { Std. } \\
\text { Deviation }\end{array}$ & $\mathrm{T}$ & df & Sig \\
\hline \hline \multirow{2}{*}{ Fluency } & Control & $\mathbf{3 6}$ & $\mathbf{5 . 9 7}$ & $\mathbf{1 . 7 2}$ & \multirow{2}{*}{$\mathbf{0 . 4 7}$} & $\mathbf{7 0}$ & $\begin{array}{l}\mathbf{0 . 6 4 2} \\
\text { Not sig }\end{array}$ \\
\cline { 2 - 7 } & Experimental & $\mathbf{3 6}$ & $\mathbf{6 . 1 7}$ & $\mathbf{1 . 8 3}$ & \multicolumn{2}{|c}{} \\
\hline
\end{tabular}




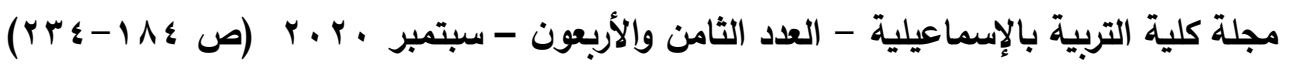

\begin{tabular}{|c|c|c|c|c|c|c|c|}
\hline \multirow{2}{*}{ Pronunciation } & Control & 36 & 7.25 & 2.23 & \multirow{2}{*}{0.67} & \multirow{2}{*}{70} & \multirow{2}{*}{$\begin{array}{l}\mathbf{0 . 5 0 8} \\
\text { Not sig } \\
\end{array}$} \\
\hline & Experimental & 36 & 6.89 & 2.36 & & & \\
\hline \multirow{2}{*}{ Grammar } & control & 36 & 6.61 & 2.02 & \multirow{2}{*}{0.06} & \multirow{2}{*}{70} & \multirow{2}{*}{$\begin{array}{l}\mathbf{0 . 9 5 5} \\
\text { Not sig } \\
\end{array}$} \\
\hline & Experimental & 36 & 6.58 & 2.20 & & & \\
\hline \multirow{2}{*}{ Vocabulary } & Control & 36 & 6.33 & 1.77 & \multirow{2}{*}{0.96} & \multirow{2}{*}{70} & \multirow{2}{*}{$\begin{array}{l}\mathbf{0 . 3 4 2} \\
\text { Not sig } \\
\end{array}$} \\
\hline & Experimental & 36 & 5.94 & 1.67 & & & \\
\hline \multirow{2}{*}{ Comprehension } & Control & 36 & 6.61 & 2.28 & \multirow{2}{*}{0.05} & \multirow{2}{*}{70} & \multirow{2}{*}{$\begin{array}{l}\mathbf{0 . 9 5 9} \\
\text { Not sig } \\
\end{array}$} \\
\hline & Experimental & 36 & 6.58 & 2.31 & & & \\
\hline \multirow{2}{*}{$\begin{array}{l}\text { Nonverbal } \\
\text { communication }\end{array}$} & Control & 36 & 5.56 & 1.13 & \multirow{2}{*}{1.08} & \multirow{2}{*}{70} & \multirow{2}{*}{$\begin{array}{l}\mathbf{0 . 2 8 3} \\
\text { Not sig } \\
\end{array}$} \\
\hline & Experimental & 36 & 5.97 & 2.00 & & & \\
\hline \multirow{2}{*}{ Total } & Control & 36 & 38.33 & 7.60 & \multirow{2}{*}{0.09} & \multirow{2}{*}{70} & \multirow{2}{*}{$\begin{array}{l}0.924 \\
\text { Not sig }\end{array}$} \\
\hline & Experimental & 36 & 38.13 & 9.57 & & & \\
\hline
\end{tabular}

The analysis of the results indicates that there are no statistically significant differences between the experimental and the control groups at $(0.05)$ level. This means that the two groups are equivalent.

b. The treatment

The experiment lasted for four weeks with three sessions per week and each session lasted for about 90 minutes. The first session was introductory as the experimental group was told about the aims and the importance of using self-study strategies. They were also told about the steps of each strategy. During the other sessions, the developed learning materials based on self-study strategies were taught to the experimental group. At the end of each session, the participants were evaluated to be sure that the session was successful. The control group was taught by another teacher using the ordinary methods who also participated in the assessment process.

c. Post test

After implementing the Learning materials based on using self-study strategies for developing speaking skills among the experimental group, the researcher administrated the speaking skills test which was previously employed as a pre-test with the same procedures to both the experimental and control groups. The means, the standard deviation, the " $t$ " value and the effect size were computed. The results were recorded and statistically analyzed as mentioned in the following section. 


\section{Results related to the first hypothesis}

The first hypothesis stated "There is a statistically significant difference between the mean scores of the experimental group in the pre administration of the speaking skills test and those of the post administration of the same test in favour of the post administration."

To test this hypothesis, paired sample t-test was used to measure if there were significant differences between the mean scores of the experimental group in the pre administration of the speaking skills test and those of the post administration of the same test in favour of the post administration. The statistical results are shown in the following table (3) :

Table (3): T-test of the Experimental group in the pre-post test

\begin{tabular}{|c|c|c|c|c|c|c|c|c|}
\hline & Application & $\mathbf{N}$ & Mean & $\begin{array}{l}\text { Std. } \\
\text { Deviation }\end{array}$ & $\mathbf{T}$ & df & Sig & $\begin{array}{l}\text { Effect } \\
\text { size }\end{array}$ \\
\hline \multirow{2}{*}{ Fluency } & Pre test & 36 & 6.17 & 1.83 & \multirow{2}{*}{49.51} & \multirow{2}{*}{35} & \multirow{2}{*}{$\begin{array}{l}0.000 \\
\text { sig }\end{array}$} & \multirow{2}{*}{$\begin{array}{l}0.986 \\
\text { High }\end{array}$} \\
\hline & Post test & 36 & 16.69 & 2.10 & & & & \\
\hline \multirow{2}{*}{ Pronunciation } & Pre test & 36 & 6.89 & 2.36 & \multirow{2}{*}{50.24} & \multirow{2}{*}{35} & \multirow{2}{*}{$\begin{array}{l}0.000 \\
\text { sig }\end{array}$} & \multirow{2}{*}{$\begin{array}{l}0.986 \\
\text { High }\end{array}$} \\
\hline & Post test & 36 & 16.97 & 2.38 & & & & \\
\hline \multirow{2}{*}{ Grammar } & Pre test & 36 & 6.58 & 2.20 & \multirow{2}{*}{37.13} & \multirow{2}{*}{35} & \multirow{2}{*}{$\begin{array}{l}0.000 \\
\text { sig }\end{array}$} & \multirow{2}{*}{$\begin{array}{l}0.975 \\
\text { High }\end{array}$} \\
\hline & Post test & 36 & 17.25 & 2.51 & & & & \\
\hline \multirow{2}{*}{ Vocabulary } & Pre test & 36 & 5.94 & 1.67 & \multirow{2}{*}{34.94} & \multirow{2}{*}{35} & \multirow{2}{*}{$\begin{array}{l}0.000 \\
\text { sig }\end{array}$} & \multirow{2}{*}{$\begin{array}{l}0.972 \\
\text { High }\end{array}$} \\
\hline & Post test & 36 & 17.03 & 2.25 & & & & \\
\hline \multirow{2}{*}{ Comprehension } & Pre test & 36 & 6.58 & 2.31 & \multirow{2}{*}{25.23} & \multirow{2}{*}{35} & \multirow{2}{*}{$\begin{array}{l}\text { 0.000 } \\
\text { sig }\end{array}$} & \multirow{2}{*}{$\begin{array}{l}0.948 \\
\text { High }\end{array}$} \\
\hline & Post test & 36 & 16.58 & 2.69 & & & & \\
\hline \multirow{2}{*}{$\begin{array}{l}\text { Nonverbal } \\
\text { communication }\end{array}$} & Pre test & 36 & 5.97 & 2.01 & \multirow{2}{*}{22.58} & \multirow{2}{*}{35} & \multirow{2}{*}{$\begin{array}{l}0.000 \\
\text { sig }\end{array}$} & \multirow{2}{*}{$\begin{array}{l}0.936 \\
\text { High }\end{array}$} \\
\hline & Post test & 36 & 15.81 & 2.84 & & & & \\
\hline \multirow{2}{*}{ Total score } & Pre test & 36 & 38.14 & 9.57 & \multirow{2}{*}{45.35} & \multirow[b]{2}{*}{35} & \multirow{2}{*}{$\begin{array}{l}0.000 \\
\text { sig }\end{array}$} & \multirow{2}{*}{$\begin{array}{l}0.983 \\
\text { High }\end{array}$} \\
\hline & Post test & 36 & 100.33 & 14.08 & & & & \\
\hline
\end{tabular}

The results in table (3) above indicated that there are statistically significant differences at $(\alpha \leq 0.05)$ between the mean scores of the experimental group in the pre administration of the speaking skills test and those of the post administration of the same test in favour of the post administration. This means that using self-study strategies was effective in improving the speaking skills of the experimental group. This improvement can be illustrated by the following figures ( 10 \& 11): 


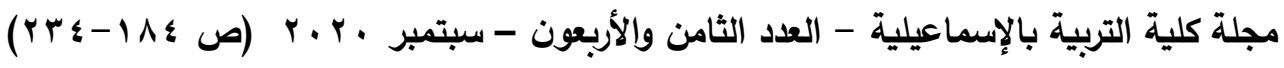

Figure (10) The mean scores of the pre and post test of the experimental group in each criterion

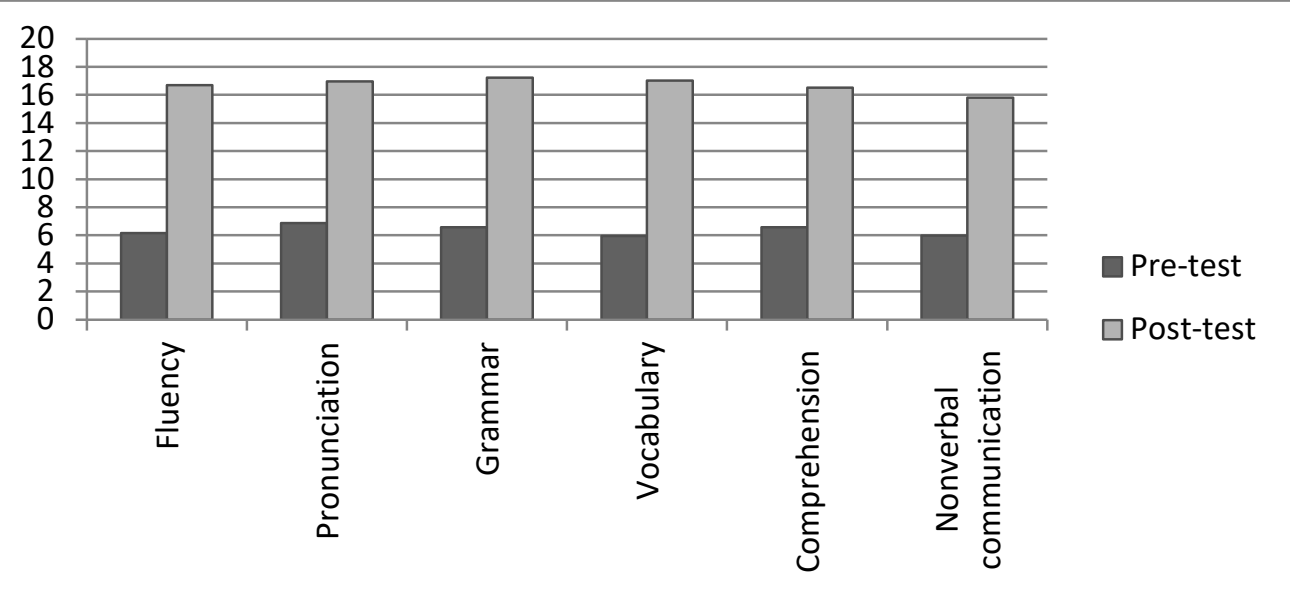

Figure (11) The total scores mean of the pre-post test of the experimental group

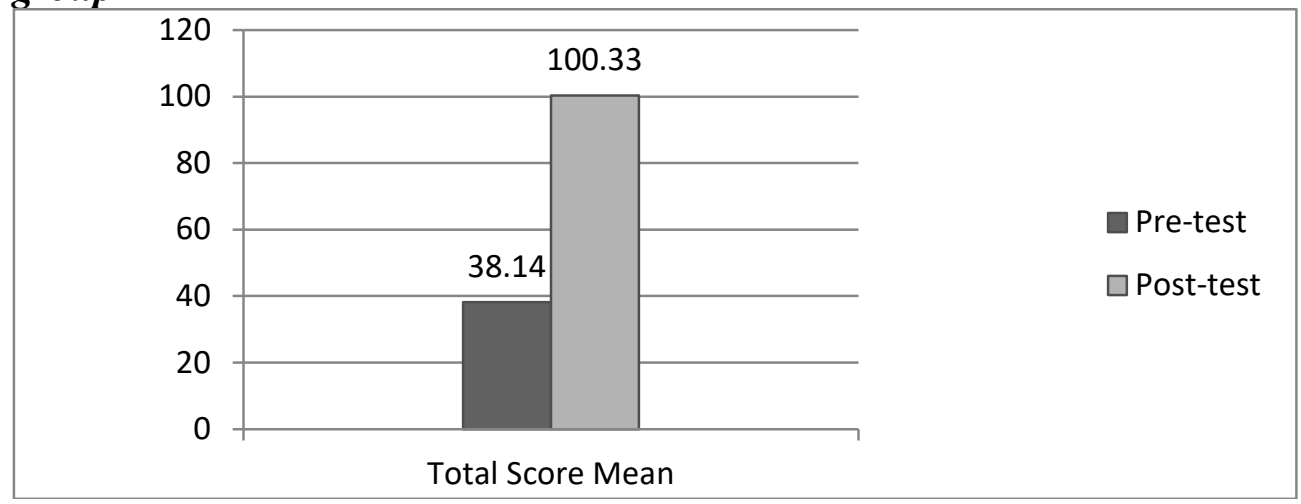

Data in table (3) also showed that the effect size of self-study strategies is high on developing the speaking skills among the experimental group. Thus, it has been proved that the self-study strategies had a positive effect on improving the speaking skills of the preparatory pupils and the hypothesis is accepted in this study.

\section{Results related to the second hypothesis}

The second hypothesis stated "There is a statistically significant difference between the mean scores of the experimental group and the control group on the post administration of the speaking skills test in favour of the experimental group." 
To test this hypothesis, independent sample t-test was used to measure if there were significant differences between the experimental group and the control one in the mean scores of the post administration of the speaking skills test in favour of the experimental group. The statistical results are shown in the following table (4):

Table(4): T-test of the Experimental \& Control groups on the post-test

\begin{tabular}{|c|c|c|c|c|c|c|c|c|}
\hline & Groups & $\mathbf{N}$ & Mean & $\begin{array}{l}\text { Std. } \\
\text { Deviatio } \\
\text { n }\end{array}$ & $\mathbf{T}$ & df & Sig & $\begin{array}{l}\text { Effect } \\
\text { size }\end{array}$ \\
\hline \multirow{2}{*}{ Fluency } & Control & $\begin{array}{l}3 \\
6\end{array}$ & 14.92 & 2.10 & \multirow{2}{*}{$\begin{array}{l}3.1 \\
8\end{array}$} & \multirow{2}{*}{$\begin{array}{l}7 \\
\mathbf{0}\end{array}$} & \multirow{2}{*}{$\begin{array}{l}0.002 \\
2 \\
\text { sig }\end{array}$} & \multirow{2}{*}{$\begin{array}{l}0.127 \\
\text { moderat } \\
\text { e }\end{array}$} \\
\hline & $\begin{array}{l}\text { Experiment } \\
\text { al }\end{array}$ & $\begin{array}{l}3 \\
6 \\
\end{array}$ & 16.69 & 2.14 & & & & \\
\hline \multirow{2}{*}{ Pronunciation } & Control & $\begin{array}{l}3 \\
6 \\
\end{array}$ & 15.33 & 2.99 & \multirow{2}{*}{$\begin{array}{l}2.5 \\
7\end{array}$} & \multirow{2}{*}{$\begin{array}{l}7 \\
\mathbf{0}\end{array}$} & \multirow{2}{*}{$\begin{array}{l}0.012 \\
4 \\
\text { sig }\end{array}$} & \multirow{2}{*}{$\begin{array}{l}0.086 \\
\text { moderat } \\
\mathrm{e}\end{array}$} \\
\hline & $\begin{array}{l}\text { Experiment } \\
\text { al }\end{array}$ & $\begin{array}{l}3 \\
6 \\
\end{array}$ & 16.97 & 2.38 & & & & \\
\hline \multirow{2}{*}{ Grammar } & Control & $\begin{array}{l}3 \\
6\end{array}$ & 15.08 & 2.51 & \multirow{2}{*}{$\begin{array}{l}3.5 \\
7\end{array}$} & \multirow{2}{*}{$\begin{array}{l}7 \\
\mathbf{0}\end{array}$} & \multirow{2}{*}{$\begin{array}{l}0.000 \\
6\end{array}$} & \multirow{2}{*}{$\begin{array}{l}\text { 0.154 } \\
\text { High }\end{array}$} \\
\hline & $\begin{array}{l}\text { Experiment } \\
\text { al }\end{array}$ & $\begin{array}{l}3 \\
6\end{array}$ & 17.25 & 2.64 & & & & \\
\hline \multirow{2}{*}{ Vocabulary } & Control & $\begin{array}{l}3 \\
6\end{array}$ & 14.83 & 2.91 & \multirow{2}{*}{$\begin{array}{l}3.5 \\
8\end{array}$} & \multirow{2}{*}{$\begin{array}{l}7 \\
\mathbf{0}\end{array}$} & \multirow{2}{*}{$\begin{array}{l}0.000 \\
6 \\
\text { sig }\end{array}$} & \multirow{2}{*}{$\begin{array}{l}0.155 \\
\text { High }\end{array}$} \\
\hline & $\begin{array}{l}\text { Experiment } \\
\text { al }\end{array}$ & $\begin{array}{l}3 \\
6 \\
\end{array}$ & 17.03 & 2.25 & & & & \\
\hline \multirow{2}{*}{$\begin{array}{l}\text { Comprehensio } \\
\text { n }\end{array}$} & Control & $\begin{array}{l}3 \\
6 \\
\end{array}$ & 14.03 & 3.48 & \multirow{2}{*}{$\begin{array}{l}3.4 \\
9\end{array}$} & \multirow{2}{*}{$\begin{array}{l}7 \\
\mathbf{0}\end{array}$} & \multirow{2}{*}{$\begin{array}{l}0.000 \\
8 \\
\text { sig }\end{array}$} & \multirow{2}{*}{$\begin{array}{l}0.148 \\
\text { High }\end{array}$} \\
\hline & $\begin{array}{l}\text { Experiment } \\
\text { al }\end{array}$ & $\begin{array}{l}3 \\
6 \\
\end{array}$ & 16.58 & 2.69 & & & & \\
\hline \multirow{2}{*}{$\begin{array}{l}\text { Nonverbal } \\
\text { communicatio } \\
\text { n }\end{array}$} & Control & $\begin{array}{l}3 \\
6 \\
\end{array}$ & 13.97 & 3.25 & \multirow{2}{*}{$\begin{array}{l}2.5 \\
5\end{array}$} & \multirow{2}{*}{$\begin{array}{l}7 \\
\mathbf{0}\end{array}$} & \multirow{2}{*}{$\begin{array}{l}0.012 \\
8 \\
\text { sig }\end{array}$} & \multirow{2}{*}{$\begin{array}{l}\text { 0.085 } \\
\text { Moderat } \\
\text { e }\end{array}$} \\
\hline & $\begin{array}{l}\text { Experiment } \\
\text { al } \\
\end{array}$ & $\begin{array}{l}3 \\
6 \\
\end{array}$ & 15.81 & 2.84 & & & & \\
\hline \multirow{2}{*}{ Total } & Control & $\begin{array}{l}3 \\
6\end{array}$ & 88.17 & 16.30 & \multirow{2}{*}{$\begin{array}{l}3.3 \\
9\end{array}$} & \multirow{2}{*}{$\begin{array}{l}7 \\
\mathbf{0}\end{array}$} & \multirow{2}{*}{$\begin{array}{l}0.001 \\
2 \text { sig }\end{array}$} & \multirow{2}{*}{$\begin{array}{l}\text { 0.141 } \\
\text { High }\end{array}$} \\
\hline & $\begin{array}{l}\text { Experiment } \\
\text { al }\end{array}$ & $\begin{array}{l}3 \\
6 \\
\end{array}$ & $\begin{array}{l}100.3 \\
3 \\
\end{array}$ & 14.08 & & & & \\
\hline
\end{tabular}

The results in table (4) above indicated that the mean scores of both groups in the post administration of the speaking skills test were high but the experimental group had a higher mean score than the control one. Thus, there are statistically significant differences at $(\alpha \leq 0.05)$ between the mean scores of the experimental and control groups in the post administration of the speaking skills test in favour of the 


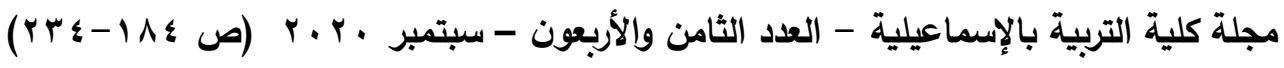

experimental group. This means that using the self-study strategies was more effective in improving the speaking skills of the preparatory pupils than using the ordinary methods as they help in creating a proper positive environment for speaking skills which make pupils feel relaxed and enjoy participating in speaking activities and rarely get bored and tired. They also allow pupils to make best use of learning opportunities in and out of the classroom and take more responsibility for their own learning.

These results also indicates that the hypothesis is accepted. This improvement can be illustrated by the following figures ( 12 \& 13 ):

Figure (12): The mean score of the experimental and control groups in the post-test

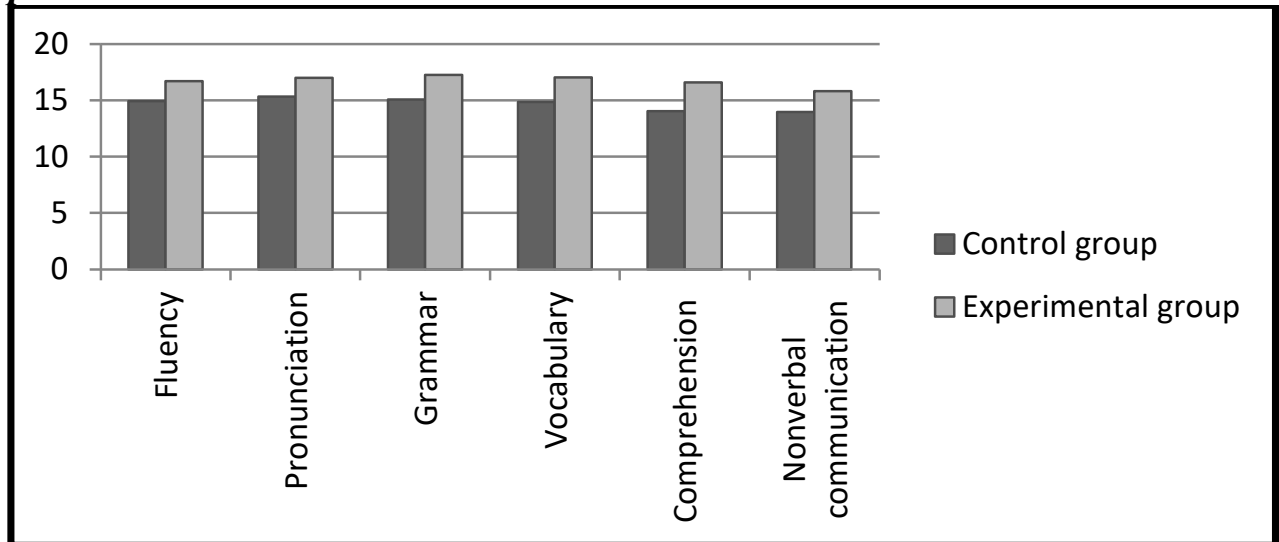

Figure (13):The total score mean of the experimental and control groups in the post-test

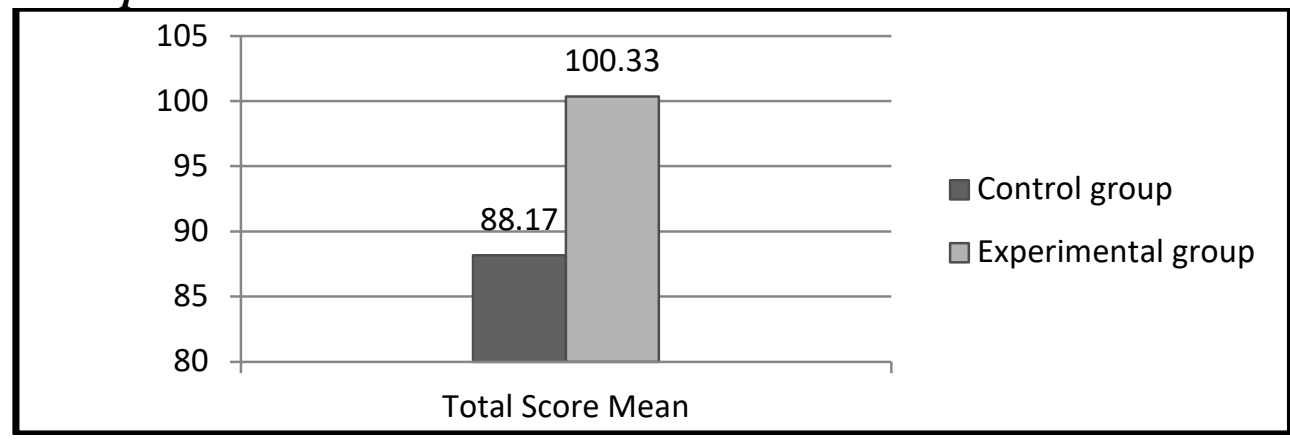

According to the results shown in table (4) the effect size of using selfstudy strategies on the experimental group in teaching speaking skills is high in the levels of vocabulary, grammar and comprehension but it is moderate in fluency, nonverbal communication and pronunciation levels. 
Results in table (4) also showed that according to the degree of the effect size of using self-study strategies on the experimental group in teaching speaking skills, vocabulary came on the first rank where $\eta^{2}=$ (0.155) followed by grammar which came on the second rank where $\eta^{2}$ $=(0.154)$, then comprehension on $\eta^{2}=(0.148)$ and fluency on $\eta^{2}=($ 0.127 ). Finally, pronunciation on $\eta^{2}=(0.086)$ and nonverbal communication on $\eta^{2}=(\mathbf{0 . 0 8 5})$ came on the last rank with a difference between them. The moderate effect on pronunciation and nonverbal communication levels means that pupils might have needed more practice.

To conclude, the results of the present study revealed significance at (0.05) between the mean scores of the experimental group in developing speaking skills in favour of their posttest. They also revealed significance at $(0.05)$ between the mean scores of the experimental and control groups in the speaking skills post-test in favour of the experimental group.

Accordingly, the results of the present study showed that using selfstudy strategies proved to be useful and effective in developing the preparatory pupils' speaking skills compared to the ordinary methods. Self-study strategies proved to be useful and effective in developing speaking skills among preparatory stage pupils due to the following :

1. They help teachers create a proper positive environment for speaking skills.

2. They also help pupils build self-confidence to express themselves orally.

3. They help pupils organize ideas before speaking process and recall them easily during.

4. They make pupils feel relaxed and enjoy participating in speaking activities.

5. They encourage social interaction with peers among pupils.

\section{Conclusion}

In light of the findings of the current study, it can be concluded that using self-study strategies proved to be useful and effective in developing the preparatory pupils' speaking skills compared to the ordinal methods. This may be due to the following :

1. They help teachers create a proper positive environment for speaking skills.

2. They help teachers save great amount of time and energy. 


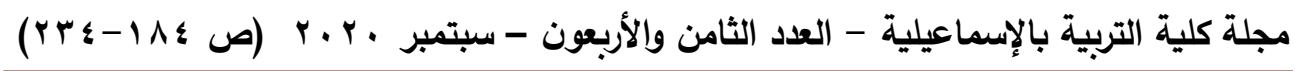

3. They make pupils feel relaxed and enjoy participating in speaking activities and rarely get bored and tired.

4. They allow pupils to make best use of learning opportunities in and out of the classroom.

5. They help pupils take more responsibility for their own learning.

6. They make pupils more motivated to think and work independently.

7. They help pupils build self-confidence in the process of speaking learning to express themselves orally.

8. They help pupils organize ideas before speaking process and recall them easily during.

9. They encourage social interaction with peers among pupils.

10. They help pupils identify their weaknesses as well as their strengths and solutions.

11. They help Pupils become producers of language rather than simply learners of a linguistic system.

12. They enable pupils to create and make use of all the opportunities to communicate and express their opinions and ideas in English.

\section{Recommendations}

In light of the present study results and conclusions, it is recommended that:

1. Teachers of EFL should encourage their pupils to use self-study strategies in learning speaking skills to develop their speaking proficiency.

2. Teachers should adopt self-study strategies in teaching speaking.

3. Teachers should establish a proper positive learning environment for language learning using pair work and group work which help in making the learning process to be successful.

4. EFL supervisors and teachers should be trained on the use of selfstudy strategies to improve their teaching of speaking skills.

5. Speaking instruction should be given more attention in our EFL classes.

6. Text books authors should include some self-study tasks in learning English.

7. Books that stress speaking through the use of self-study strategies should be suggested.

8. Speaking skills should be included in exams.

9. Pupil-centered approaches should be adopted in our classrooms. 
10. Pupils should share more responsibilities in their learning of speaking skills.

11. Pupils should be offered enough opportunities to practice speaking in EFL classes.

12. Pupils should be offered opportunities to self evaluate their oral performance.

13. Pupils need to extensively practice speaking in their daily activities to be good at speaking.

14. Pupils should prepare themselves especially before joining the class. 15. Listening skill which is related to the idea of developing perfect pronunciation, stress and intonation should be developed. 


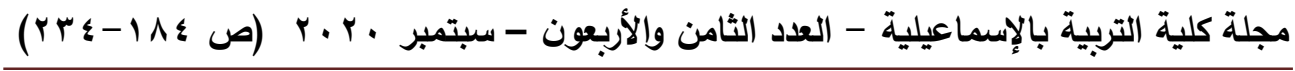

References

Academic Skills Center California Polytechnic State University San Luis Obispo, California ASC Study Skills Library Kennedy Library 112, 805-756-1256 from http://sas. calpoly. edu/asc/ssl.html . Retrieved on October $3^{\text {rd }}, 2016$.

American Heritage Dictionary of the English Language (2013) https://ahdictionary.com/ word/search.html?q=self-study. Retrieved on March $20^{\text {th }}, 2013$.

Badr, B. (2009). The Effect of Using Some Active Learning Techniques on Developing Primary Pupil's Speaking Skills. Unpublished M.A Thesis. Ain Shams University. Faculty of Education.

Beck, C., Freese, A., \& Kosnik, C. (2004). The Preservice Practicum: Learning through Self-Study in a Professional Setting. In John Loughran, MaryLynn Hamilton, Vicki LaBoskey \& Tom Russell (Eds.), International Handbook of Self-study of Teaching and Teacher Education Practices (pp. 1259-1293). Dordrecht: The Netherlands: Kluwer Academic Publishers.

Benson, P. (2001). Teaching and researching autonomy in language learning. London: Longman.

Biggs, J. (2003). Teaching for quality learning at university. Buckingham: The Society for Research into Higher Education and Open University Press $\left(2^{\text {nd }} \mathbf{E d}\right)$.

Bocanegra, A., Haidl, A. \& Cadiz, U. (1999). Language learner autonomy in pracitce: possibilities in a foreign language situation. Revista Alicantina de Estudios Ingleses, 12(1), 7-17. Retrieved on $10^{\text {th }}$ June, 2015 from http://rua.ua.es/dspace/ bitstream/ 10045/5950/1/RAEI 12 01.pdf

Brown, H. (2001). Characteristic of successful speaking activities. New York: Cambridge University press.

Cambridge Dictionary (2016), from https://dictionary.cambridge.org/dictionary/english/self-study. Retrieved on May 20th , 2016.

Clarke, A. \& Erickson, E. (2003). Teacher inquiry: Living the research in everyday practice. New York: Routledge Falmer.

Cochran-Smith, M., \& Lytle, S. (2009). Inquiry as stance: Practitioner research for the next Generation. New York, NY: Teachers College Press.

Cynthia, A., Galman, S. \& Kosnik, C. (2009). Self-Study Research Methodologies for Teacher Educators. Sense Publishers, P.O. Box 
21858, 3001 AW Rotterdam, The Netherlands. Retrieved on June $4^{\text {th }}, 2016$ from http://www.sensepublishers.com

Eggins, S., Slade, D. (1997). Analyzing Casual Conversation. London: Cassell. Chapter 6.

Fisher, J., \& Schumaker, J., (1995). Searching for validated inclusive practices: A review of the literature focus on Exceptional Children, 89, (2), 1-20.

Friedman, M. ( 2014 ). Notes on Note-Taking: Review of Research and Insights for Pupils and Instructors. Harvard Initiative for Learning and Teaching: Harvard University. From https://www.semanticscholar.org/paper/Notes-on-Note-taking-

Review-of-Research -andFriedman/190510716970cdca8a23894556590b31c9f65b6b

Gillis, G. (2013). The Importance of Speaking Skills. Retrieved on June $1^{\text {st }}, 2014$ from http://www.geraldgillis.com/importance-speaking$\underline{\text { skills/ }}$

Gökgöz, B. (2008). An Investigation Of Learner Autonomy and Strategies For Coping With Speaking Problems In Relation To Success In English Speaking Classes. M.A. Thesis OF Arts in The Department of English Language Teaching. Middle East Technical University.

Hamilton, M., Pinnegar, S., Russell, T., Loughran, J., \& LaBoskey, V. K. (Eds.). (1998). Reconceptualizing teaching practice: Self-study in teacher education. London: Falmer Press.

Harmer, J. ( 1983). The Practice of English Language Teaching. $\left(6^{\text {th }}\right)$, New York: Longman Group. University Press.

Haroun, A. (2012). The Effectiveness of Teaching Digital stories in Developing EFL Primary Pupils' Speaking Skill. Unpublished M.A. Thesis. Ain shams University. Faculty of Education.

Hinkel, E. (Ed.) (2005). Handbook of Research in Second Language Teaching and Learning. Hillsdale, NJ: Lawrence Erlbaum Associates, Inc.

Holec, H. (1981). Autonomy and Foreign Language Learning. Oxford: Pergamon.

Hornby, A. (1995). Oxford advanced learner's dictionary. Oxford: Oxford University Press.

Hornby, A. (2007). Oxford advanced learner's dictionary. Oxford: Oxford University Press.

Hozayen, G. (2011). Egyptian Pupils' Readiness for Autonomous Language Learning. In Gender, D. (Ed.), Fostering autonomy in 


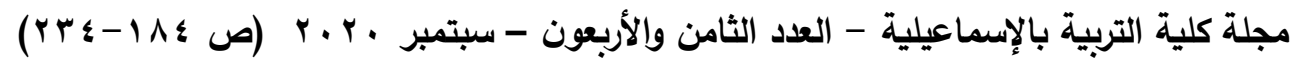
language learning (pp. 115-125). Gaziantep: Zirve University. Retrieved from http://ilac2010.zirve.edu.tr on July $10^{\text {th }}, 2017$.

Ibrahim, D. (2007).The Effectiveness of Some Cooprative Learning Strategies In Developing Preparatory School Pupils' English Speaking Skills. Unpublished M.A Thesis. Zgazig University. Faculty of Education.

Irawati, I. (2014). Improving pupils' speaking ability through communicative language games. Magistra, 87( XXV), 25-36.

Jamila, M. (2013 Nov. - Dec.). Use of Learner Autonomy in Teaching Speaking by Tertiary Level English Language Teachers in Private Universities of Bangladesh. IOSR Journal Of Humanities And Social Science (IOSR-JHSS), 18 (4), 29-43. Retrieved on $28^{\text {th }}$ June 2015 from www.iosriournals.org

Jiao, L. (2005- May). Promoting EFL Learner Autonomy. 2(5), (Serial No.17). Sino-US English Teaching Learning. London: Longman.

Johnson, D. , Johnson, R. , \& Holubec, E. (1993). Cooperation in the classroom (6th ed.). Edina, MN: Interaction Book.

Khodabandehlou, M., Jahandar, S., Seyedi, G. \& Abadi, R. (2012June). The Impact of Self-directed Learning Strategies on Reading Comprehension. International Journal of Scientific \& Engineering Research, 3(7). Retrieved on June 12 ${ }^{\text {th }}, 2016$ from http:// www.ijser.org

Khorashadyzadeh, A. (2014). Why to use short stories in speaking classes? International Journal of Foreign Language Teaching in the Islamic World, 2 (1), 9-15.

Knowles, M. (1970). The modern practice of adults education: Andragogy Versus Pedagogy. New York: Associated Press.

LaBoskey, V. (2004a). The methodology of self-study and its theoretical underpinnings. In J. J. Loughran, M. L. Hamilton, V. K. LaBoskey, \& T. Russell (Eds.), International handbook of self-study of teaching and teacher education practices (pp. 817-869). Correct, The Netherlands: Kluwer Academic Publishers.

Little, D. (1995). Learning as dialogue: The dependence of learner autonomy on teacher autonomy. System, 23 (2), 175-181. Retrieved on June $5^{\text {th }}, 2016$ from http://eprints. teaching and learning.ie/2753/

Little, D. (2002a). Learner autonomy and second/foreign language learning. In The guide to good practice for learning and teaching in languages, linguistics and area studies. University of Southampton: LTSN Subject Centre for Languages, Linguistics and Area Studies. 


$\begin{array}{lllll}\text { Retrieved on July } 10^{\text {th }} \quad, & 2014 & \text { from }\end{array}$
http://www.lang.Itsn.ac.uk/resources/ guidecontents.aspx.

Little, D. (2006). The Common European Framework of Reference for Languages: Contents, purpose, origin, reception and impact. Language Teaching, 39(3),167-190.

Little, D. 2004. Democracy, discourse and learner autonomy in the foreign language classroom. Utbildning \& Demokrati, 13(3), 105126.

Liu, Y. (2012). Exploring autonomous learning strategies within contemporary dance technique class at the South China Normal University. Retrieved from ausdance.org.au/uploads/content/publications/2012-globalsummit/teaching-dance-rp/ exploring-autonomous-learningstrategies-within-contemporary-dance-technique-class-1.pdf

Loughran, J. , Hamilton, M. , LaBoskey, V. , \& Russell, T. (Eds.). (2004). International handbook of self-study of teaching and teacher education practices. Dordrecht: Kluwer Academic Publishers.

Markley, D., \& Jefferies, D. (2000). Guidelines for implementing a graphic organizer. The Reading Teacher, 54(4), 35-357.

Marzano, R. , Norford, J. , Paynter, D. , Pickering, D. , Gaddy, B. (2001). A handbook for classroom instruction that works. Alexandria, VA: Association for Supervision and Curriculum Development.

Marzano, R. , Norford, J., Paynter, D. , Pickering, D. , \& Gaddy, B. , (2000). What Works in Classroom Instruction. Mid-continent Research for Education and Learning. McREL

Merrett, F. \& Thorpe, S. (1996). How Important Is the Praise Element in the Pause, Prompt and Praise Tutoring Procedures for Older Low-Progress Reader? Educational Psychology, 16(2),193.

Mirza, A. (2016). The Use of Mind Mapping Strategy to Improve Students' Speaking Ability. Thesis for the Sarjana Degree(S-1)on Teacher Education. Faculty of Tarbiyah and Teacher Training Islamic State University of Ar-Raniry Darussalam Banda Aceh. Retrieved from https://repository.ar-raniry. ac.id/826/1/asrifal\%20mirza.pdf

Murray, G. (2009b). Self-access language learning: Structure, control and responsibility. In F. Kjisik, P. Voller, N. Aoki \& Y. Nakata (Eds.), Mapping the terrain of learner autonomy: Learning environments, learning communities and identities (pp. 118-142). Tempere, Finland: Tampere University Press. 


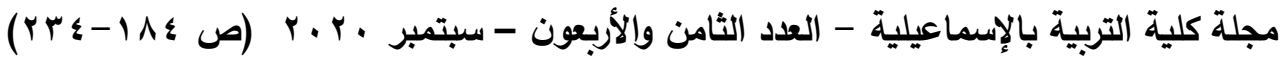

Nawaz, H. (2005). Developing speaking skill of the pupils through role play techniques at the middle level. M.A TEFL Research Thesis. Allama Iqpal Open University Islamabad. Department of English language and applied linguistics.

Note-Taking.(n.d.) Retrieved from https://www.skillsyouneed.com/write/notes-verbal.html

Note Taking Systems. (n.d.). Academic Skills Center (ASC). Student Academic Services (SAS) California Polytechnic State University San Luis Obispo, California. Retrieved from https://asc.calpoly.edu/ssl/notetakingsystems

Note Taking Strategies.(n.d.). Penn State University Center for Academic Achievement 200 University Drive; Schuylkill Haven, PA 17972 385-6140.

Retrieved

from https://canadacollege.edu/disabilityresourcecenter/docs/Note Takin g Strategies.pdf

Nunan, D. (2003). Practical English Language Teaching. Boston: McGraw Hill.

Nunan, D. (1999). Second language teaching and learning. Boston: Heinle and Heinle Publishers.

Oxford Dictionary of Current English. ( 2009). Oxford: Oxford University Press.

Palfreyman, D. (2003). Introduction: Culture and learner autonomy. In D. Palfreyman \& R. C. Smith (Eds.) (2003). Learner autonomy across cultures: Language education perspectives (pp. 1-19). Basingstoke: Palgrave Macmillan.

Pinnegar, S. (1998). Methodological perspectives: Introduction. In M. L. Hamilton et al, (Eds.) Reconceptualizing teaching practice: Selfstudy in teacher education ( pp. 31-33) London: Falmer Press.

Piolat, A. (2001). La prise de notes [Note Taking]. Paris: Presses Universitaires de France.

Olive, T., Kellogg, R. \& Piolat, A. (2005). Cognitive effort during note taking. Applied Cognitive Psychology, 19, 291-312.

Baxendell, B. (2003, July). Considerations Packet Graphic Organizers: Guiding Principles and Effective Practice. Retrieved from https://education.wm.edu/centers/ttac/ documents/articles/graphic organizers.pdf

Richards, J. (2008). Teaching Listening and Speaking From Theory to Practice. Cambridge University Press.

Rokhmawati, E. (2011). The use of reialia to improve Pupil's speaking ability in procedures text (A Classroom Action Research with the 
Ninth Grade Pupils of MTs. Mathalibul Huda Mlonggo Jepara in the Academic Year of 2010/2011) English Depatrtment of Tarbiyah Faculty Walisongo State Institue For Islamic Studies Semarang.

Sarac, G. (2007). The Use of Creative Drama in Developing the Speaking Skills of Young Learners. Unpublished M.A Thesis. Institute of Educational Sciences. Gazi University, Ankara.

Shumin, K. (1997). Factorsto consider: Developing Adult EFL Pupils' Speaking Abilities. Retrieved on June $2^{\text {nd }}, 2014$ from http://dosfan.lib.uic.edu/usia/E-USIA/forum/vols/ vol35/no3/p8.htm

Shumin, K.(2002).Factors to Consider: Developing Adult EFL Pupils' Speaking Abilities, Methodology in Language Teaching, Cambridge: Cambridge University Press.

Shvets, O. (2012). Study Skills as a Way to Independent Language Learning. Retrieved on October $10^{\text {th }}, 2016$ from http://ir.nmu.org.ua/handle/123456789/3161

Syakur. (2007). The Components of Speaking Skill. Obtenido de Speaking. Retrieved on April $5^{\text {th }}, 2016$ from https://es.scribd.com/doc/106593833/9/The-Components-ofSpeaking-Skill

Tang, G. \& Yang, G.(2000, Winter). Learning English Through Selfstudy by New Arrival Children. Education Journal, 28( 2). The Chinese University of Hong Kong.

Tarigan, H. (1990). Membaca dalam Kehidupan. Bandung: Penerbit Angkasa. Retrieved on August 10 $^{\text {th }}, \quad 2014$, from http://eric.indiana.edu.

Tayib, A. (2015, January). The Effect of Using Graphic Organizers on Writing (A case study of preparatory college students at Umm-ALQura University). International Journal of English Language and Linguistics Research, 3(1), 15-36, entwww.eajournals.org UK Published (by European Centre for Research Training and Development www.eajournals.org UK

Terry, C. (2008). How to teach speaking in an EFL class? Retrieved on May $31^{\text {st }}, 2014$ from http://www.slideshare.net/suartini/how-toteach-speaking-in-an-efl-class-ii-carolina-terry

Thanasoulas, D. (2000-November). What is Learner Autonomy and How Can It Be Fostered? The Internet TESL Journal, VI, (11). Retrieved on June $2^{\text {th }}, \quad 2015$ from http://iteslj.org/Articles/Thanasoulas-Autonomy.html

Thornbury, S. \& Slade, D. (2006). Conversation: from description to pedagogy. Cambridge: Cambridge University Press. 


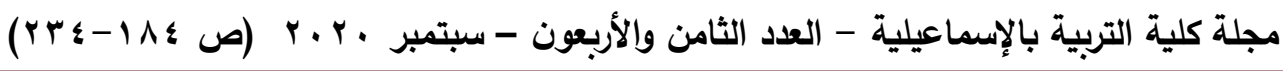

Thornbury, S. (2005). How to teach speaking. Essex: Pearson Longman.

Usman, A. (2015). Using the Think-Pair-Share Strategy to Improve Students' Speaking Ability at Stain Ternate. Journal of Education and Practice (Online) 6(10), 37-45 Retrieved from https://files.eric.ed.gov/fulltext/EJ1081679.pdf

Wilson, J. (1997). A Program to Develop the Listening and Speaking Skills of Children in a First Grade Classroom (EDRS:ED 415 566). In Badr, A. Abdel Kafy (2009). The Effect of Using Some Active Learning Techniques on Developing Primary Pupil's Speaking Skills.

Wong, L. (2006). Essential study skills (5th ed.). Boston, MA: Houghton Mifflin.

Yellen, Blake, \& DeVries (2004). Developing Speaking Skills: Notes from Integrating the Language Arts, $\left(3^{\text {rd }}\right.$ Ed). Holcomb Hathaway Publisher, Scottsdale, AZ, P.2.

Youssef, A. (2006). The beliefs of Arab university learners about their readiness for autonomy in a web-based setting: A case study. Unpublished MA Thesis, American University in Cairo, Egypt. 


\section{Abstract}

The purpose of this study was to investigate the effectiveness of using self-study strategies on developing the speaking skills among EFL preparatory pupils. The research design was the qusai experimental pre-post test design. Two classes from the first year preparatory pupils were selected purposefully from Al Oboor Preparatory School for Girls in Ismailia. One class was the experimental group and the other was the control one. Each group consisted of (36) female pupils. The treatment was administrated during the second term of the school year (20172018). The experimental group was taught by using self-study strategies while the ordinary methods were used in teaching the control one. A speaking skills test was designed and validated to be used as a pre and post test for the two groups. In order to analyze the data from the pre and post speaking test and to measure the effect of the developed learning materials, the statistical package for the social science (SPSS) was used. The statistical methods were used included t-test paired sample, t- test independent sample and the effect size technique (Eta Square). The results of the study proved that using self-study strategies had a significantly positive effect on speaking skills for this sample of preparatory school pupils as they help in creating a proper positive environment for speaking skills which make pupils feel relaxed and enjoy participating in speaking activities and rarely get bored and tired. They also allow pupils to make best use of learning opportunities in and out of the classroom and take more responsibility for their own learning.

Key Words: self-study strategies, speaking skills, English Language Teaching, Egypt. 


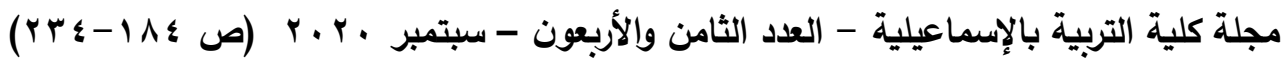
الملخص

هدفت هذه الاراسة إلى التحقق من فعالية استخدام استراتيجيات الدراسة الذاتية فى تنمية مهارات التحدث باللغة الإنجليزية لاى طلاب المرحلة الإعدادية، استخدم الباحث المنهج

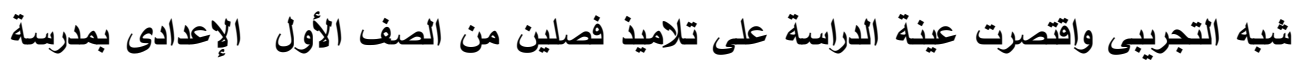

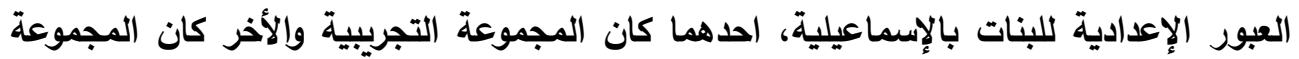
الضابطة ـ تألفت كل مجموعة من (؟؟Y) طالبة ـ تمت الاراسة خلال الفصل الدراسي الثاني من

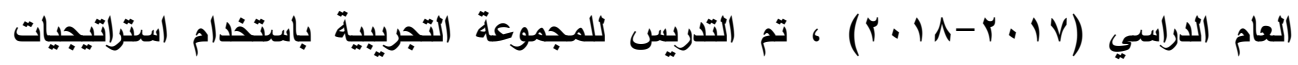
الدراسة الذاتية في حين تم استخدام الطُرُق المُعتادة في التدريس للمجموعة الضابطة. تم تصميم اختبار مهارات التحدث والتحقق من صدق الاختبار وثباته وصلاحيته للاستخدام كاختبار قبلى

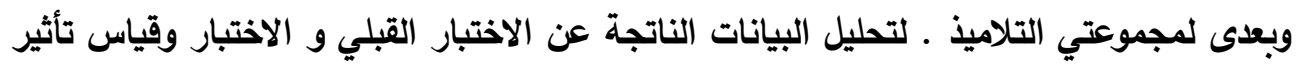
المواد التعليمية المتقدمة ، تم استخدام برنامج (SPSS) وتضمنت الأساليب الإحصائية المُستخدَمة كل من اختبار (ت) لمجموعتين مرتبطين ، واختبار (ت) لمجموعتين مستقلتين، و و كذلك مربع إيتا (Eta Square) لحساب حجم التأثير.

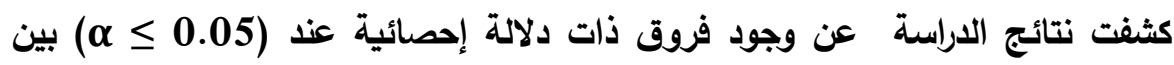
متوسطات درجات المجموعة التجريبية فى الاختبارين القبلى والبعدى في كل مستوى من مهارات

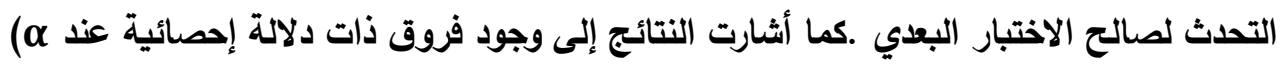
(0.05 كبين متوسطات درجات كل مستوى من مهارات التحدث في الاختبار البعدي لصالح المجموعة التجريبية مقارنة بالمجموعة الضابطة .وبالتالي ، يمكن القول أن استخدام استراتيجيات

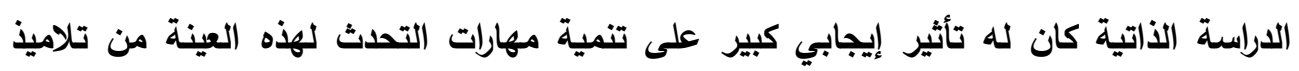
المدرسة الإعدادية.

الكلمات المفتاحية : أمتات استراتيجيات الدراسة الذاتية ، مهارات التحدث باللفة الانجليزية ،تعليم اللفة الانجليزية, المرحلة الإعدادية، جمهورية مصر العربية. 